\title{
Alzheimer and Purinergic Signaling: Just a Matter of Inflammation?
}

\author{
Stefania Merighi ${ }^{1}$, Tino Emanuele Poloni ${ }^{2}$, Anna Terrazzan ${ }^{1}$, Eva Moretti ${ }^{1}$, Stefania Gessi ${ }^{1, *}$ \\ and Davide Ferrari ${ }^{3, *}$
}

1 Department of Translational Medicine and for Romagna, University of Ferrara, 44100 Ferrara, Italy; stefania.merighi@unife.it (S.M.); anna.terrazzan@edu.unife.it (A.T.); eva.moretti@edu.unife.it (E.M.)

2 Department of Neurology and Neuropathology, Golgi-Cenci Foundation \& ASP Golgi-Redaelli, Abbiategrasso, 20081 Milan, Italy; e.poloni@golgicenci.it

3 Department of Life Science and Biotechnology, University of Ferrara, 44100 Ferrara, Italy

* Correspondence: stefania.gessi@unife.it (S.G.); dfr@unife.it (D.F.)

Citation: Merighi, S.; Poloni, T.E.; Terrazzan, A.; Moretti, E.; Gessi, S.; Ferrari, D. Alzheimer and Purinergic Signaling: Just a Matter

of Inflammation? Cells 2021, 10, 1267. https://doi.org/10.3390/cells10051267

Academic Editor: Nady Braidy

Received: 9 April 2021

Accepted: 17 May 2021

Published: 20 May 2021

Publisher's Note: MDPI stays neutral with regard to jurisdictional claims in published maps and institutional affiliations.

Copyright: (c) 2021 by the authors. Licensee MDPI, Basel, Switzerland. This article is an open access article distributed under the terms and conditions of the Creative Commons Attribution (CC BY) license (https:// creativecommons.org/licenses/by/ $4.0 /)$.

\begin{abstract}
Alzheimer's disease (AD) is a widespread neurodegenerative pathology responsible for about $70 \%$ of all cases of dementia. Adenosine is an endogenous nucleoside that affects neurodegeneration by activating four membrane $\mathrm{G}$ protein-coupled receptor subtypes, namely P1 receptors. One of them, the $\mathrm{A}_{2 \mathrm{~A}}$ subtype, is particularly expressed in the brain at the striatal and hippocampal levels and appears as the most promising target to counteract neurological damage and adenosinedependent neuroinflammation. Extracellular nucleotides (ATP, ADP, UTP, UDP, etc.) are also released from the cell or are synthesized extracellularly. They activate P2X and P2Y membrane receptors, eliciting a variety of physiological but also pathological responses. Among the latter, the chronic inflammation underlying AD is mainly caused by the P2X7 receptor subtype. In this review we offer an overview of the scientific evidence linking P1 and P2 mediated purinergic signaling to AD development. We will also discuss potential strategies to exploit this knowledge for drug development.
\end{abstract}

Keywords: Alzheimer's disease; neuroinflammation; P1 receptors; P2 receptors

\section{A Brief Update on Alzheimer's Disease (AD)}

The new classification proposed by the DSM-5 uses the term neurocognitive disorder (NCD), emphasizing that the origin of mental deficits lies in a dysfunction affecting neuronal networks. The very first stages of NCD (mild-NCD, i.e., mild cognitive impairment (MCI)) are characterized by preserved functional abilities and the capacity to be independent in daily activities. If, on the other hand, the disorder determines a functional decrement, it is defined as a major-NCD (or dementia). Further, the identification of the underlying pathology is needed for the etiological classification of the NCD [1,2]. The pathologic hallmark of NCDs that are due to AD is a double proteinopathy in which neurodegeneration is related to the deposition of amyloid-beta $(A \beta)$ and phosphorylated TAU protein (pTAU). AD is the most frequent age-related degenerative NCD that causes an impairment of multiple cognitive domains, gradually involving memory, complex attention, executive functions, language, and visual-perceptual functions. Consequently, from the beginning of the disease's course, deep changes progressively develop in personality and behavior. Conversely, due to the late involvement of the basal ganglia, motor dysfunction (i.e., parkinsonism) typically appears during the later stages of the disease. AD's syndromic evolution follows the topography of pTAU pathology from the allocortex (entorhinal cortex and hippocampus) to the neocortex, and then to basal ganglia in the terminal stages $[3,4]$. Although AD is a typical age-related pathology, the disease takes its first steps from the age of 40 onwards, with an accumulation of amyloid in the neocortex. However, amyloid deposition is very commonly found in physiological aging, thus, it is not enough to cause AD. The fundamental question of what triggers neurodegeneration remains without a 
certain answer. According to the amyloidogenic theory, neurodegeneration occurs in the presence of an excessive amount of $A \beta$, through the formation of $A \beta$ toxic oligomers. Indeed, an $\mathrm{A} \beta$ load induces neurodegeneration not per se but through soluble oligomers that disturb cellular functioning through a harmful interaction with the membrane of neurons, especially at the synaptic level. One of the most investigated mechanisms of damage to the neuronal membrane is the possible aggregation of some oligomers (e.g., $\beta_{25-35}$ ) to form anomalous ion channels (increasing the entry of $\mathrm{Ca}^{2+}$ ) or even real "pores", which can allow the chaotic entry of ions and harmful substances into the neuron $[5,6]$. All of these detrimental perturbations may induce synaptic dysfunction. The mechanisms by which oligomers cause neuronal damage are many and still little known. Instead, the final consequences of brain amyloid excess are partially known and can be summarized as follows: (1) a decrease in synaptic transmission with a dysfunction in the long-term potentiation and, consequently, a deficit in memory and other cognitive domains; (2) a decrease in the blood flow in brain capillaries; and (3) an increase in phosphorylation of the AD-relevant epitopes of the TAU protein $[7,8]$. The over-activation of neuronal kinases, resulting in unbalanced kinase/phosphatase activity, determines pTAU hyperproduction that, in turn, generates pTAU toxic oligomers and pTAU aggregation. Typically, the pathologic pTAU deposition inside the neurons spreads from its initial location in the allocortex to the neocortex. Taken together, oligomeric $A \beta$, synaptic pTAU aggregates, and glial inflammatory activation represent the main neurotoxic factors underpinning neurocognitive disorders $[9,10]$. Interpreting the neuropathological picture of AD is a key point in deciphering its pathophysiological mechanisms, from which specific biomarkers and possible therapeutic targets can be identified. Apart from brain atrophy due to synaptic rarefaction and neuronal loss, AD pathology shows an extracellular accumulation of $A \beta$ peptides (A $\beta$ or senile plaques), as well as hyperphosphorylated TAU protein aggregates inside dying neurons called neurofibrillary tangles (NFT) and neuropil threads (NT). Their combination constitutes neuritic plaque (NP), which is the hallmark of AD neuropathology that is scored using the $\mathrm{ABC}$ criteria for the post-mortem definition of an AD diagnosis. The ABC scoring system includes the following: A as Amyloid-Thal phases for an amyloid; $\mathrm{B}$ as Braak stage-a scoring system to grade the pTAU; and C as CERAD (Consortium to Establish a Registry for Alzheimer Disease) score-a scoring system to grade the number of NP [11-13].

Senile and neuritic plaques, consisting of protein and cellular debris, initiate reactive and inflammatory cascades involving astrocytes and microglia that produce cytokines (IL-1 $\beta$ and IL-6) and activate NLRP3 inflammasomes that, in turn, increase neurotoxic phenomena $[14,15]$. Moreover, a recent model for AD pathogenesis involves a modification to the protein expression and compartment functionality in the mitochondria-associated ER membrane. This sub-compartment appears enriched in presenilins and the $\beta$-amyloid producing $\gamma$-secretase complex in the APP/PS1 mouse model of AD [16]. Mitochondria has also been a focus of interest in AD research due to alterations in the voltage-dependent anion channel 1 (VDAC1) expression and, possibly, functionality [17]. VDAC-1 modulates many mitochondrial functions, including $\mathrm{Ca}^{2+}$ homeostasis, oxidative stress, energetic metabolism, and apoptotic cell death. Since overexpression of the anion channel causes apoptosis, and high VDAC1 levels have been found in post-mortem AD brains and in amyloid precursor protein (APP) transgenic mice, it has been hypothesized that VDAC1 may cause neuronal cell death characteristic of AD; therefore, VDAC1 targeting would represent a new way to inhibit neuronal cell death in AD [17].

From the neuropathological picture, specific biomarkers have been obtained, composing the ATN system (Amyloid-TAU-Neurodegeneration). This diagnostic system expresses the AD pathology and allows the in vivo definition of the disease, including the following: (1) A-amyloid evaluation (i.e., a A $\beta$ decrease in the cerebrospinal fluid (CSF) and/or an A $\beta$ cortical accumulation at amyloid-PET); (2) T-pTAU diffusion and topography in the cortex (a pTAU increase in the CSF and/or pTAU cortical accumulation at TAU-PET); and (3) N-neurodegeneration severity (an atrophic pattern in the brain MRI and/or hy- 
pometabolism at FDG-PET and/or an increase in total-TAU in the CSF) [18,19]. Biomarkers allow for an early diagnosis and even assist in identifying those most at risk of developing $\mathrm{AD}$ while still in the preclinical phase (before mild-NCD), making room for timely therapeutic interventions [20]. Nonetheless, there is currently no cure for AD and this approach poses ethical problems, as well as queries regarding invasiveness and high cost; therefore, a strong effort to identify biomarkers that are obtainable from peripheral blood is still in progress [21,22]. Due to the complexity of AD, the identification of the ideal peripheral markers appears to be a difficult challenge. The early pathogenesis of sporadic $\mathrm{AD}$ is quite complex. To exemplify the matter, just as there are different forms of hepatitis that lead to cirrhosis, there are different pathophysiological paths that lead to $\mathrm{AD}$, but the brain is much more complicated than the liver. The early mechanisms leading to an $A \beta$ accumulation and an initial generation of toxic molecules are elusive and multiple, and likely depend on individual trajectories of age-related changes. They depend on both non-modifiable genetic factors (pathogenic mutations in PSN-1-2 and APP genes, APO-E4 allele, AD-related polymorphisms) [23,24], and modifiable factors related to the individual's history. For effective preventive interventions, modifiable factors are pivotal; they include favorable behaviors (social engagement, healthy diet, high education, regular physical, and mental activity) and detrimental conditions (diabetes, hypertension, midlife obesity, excessive alcohol, smoking, and hearing loss) $[25,26]$. Education on healthy lifestyles and treatment for midlife diseases are important for people aged 40-50 years old, but this may not be enough if the disease tends to occur anyway. The early pathogenetic role of amyloid burden induced a strength effort to reduce the amyloid load in the brain, especially through the use of costly monoclonal antibodies (e.g., phase three trials: Aducanumab, Gantenerumab; phase two trial: Crenezumab). Actually, lowering the amyloid burden is only one of the possible therapeutic strategies and there is a growing interest in non-amyloid targets, with 121 agents currently being studied in ongoing clinical trials for the treatment of $\mathrm{AD}$ [27]. In particular, the development of immunotherapies capable of blocking the toxic oligomers of pTAU represent a promising strategy, and not only for $\mathrm{AD}$ [28]. The pathogenesis of AD is multi-dimensional and requires an early and personalized therapeutic approach based on both clinical and biomarker characteristics that are unique and patient specific [29-31]. Current therapies for AD can be stratified according to the stage of the disease that identifies the following three levels of intervention: (1) early prevention of risk factors and lifestyle; (2) disease-modifying treatments (a reduction in the load of $A \beta$ and toxic oligomers, the containment of the phosphorylation of TAU and toxic species of pTAU, the control of neuroinflammation, and an improvement of neuronal resilience); and (3) late symptomatic therapies (the modulation of neurotransmitters and an improvement in synaptic efficiency) [32]. However, many senile cases of AD clearly have mixed conditions of brain pathology [33] and, in the extreme stages of senility, it becomes unrealistic to halt neurodegeneration. In this context, purinergic receptors, especially in the hippocampus, constitute a new and interesting target for modulating and improving synaptic activity, and obtaining symptomatic, and possibly disease-modifying, effects.

\section{Adenosine and AD}

Adenosine is an endogenous nucleoside, omnipresent throughout the body as it is a degradation product of ATP, whose consumption is ubiquitous. Under physiological conditions, the adenosine concentration inside and outside a cell is $20-300 \mathrm{nM}$, whilst it increases to micromolar levels following pathologic conditions such as ischemia, hypoxia, and brain injury, again as a consequence of a consistent ATP degradation [34]. Indeed, both an increase in energy consumption or a decrease in energy supply induce extracellular ATP dephosphorylation and adenosine formation due to the activity of ectonucleoside triphosphate diphosphohydrolase (CD39) and ecto-5'-nucleotidase (CD73) enzymes in neurons and glial cells [35]. In addition, at an intracellular level, adenosine may be generated following an intracellular AMP degradation by a cytoplasmic $5^{\prime}$-nucleotidase, or through a hydrolysis of S-adenosyl-homocysteine (SAH) mediated by a SAH hydrolase, 
and its release is regulated through bi-directional equilibrative nucleoside transporters (ENT) [36] (Figure 1). Then, adenosine may be deaminated or phosphorylated by adenosine deaminase (ADA) or adenosine kinase (AK), with the first pathway being prevalent in pathologic conditions [37].

\section{Extracellular environment}

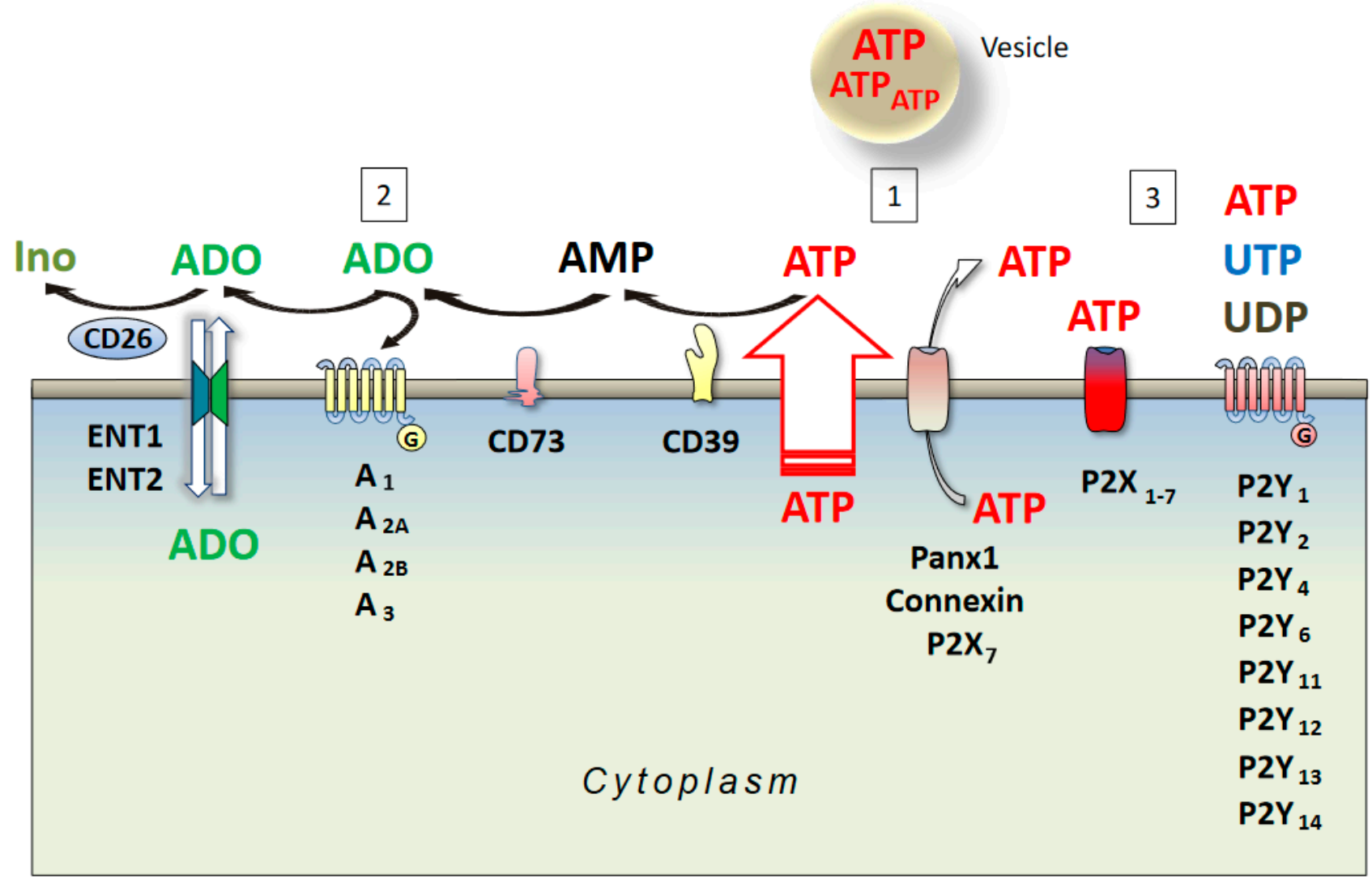

Figure 1. Membrane machinery for nucleotide and nucleoside signaling. (1) ATP can be released by the cells in different ways, among which are membrane stress/damage, and molecular (Panx1, Connexin, P2X7) and vesicular transport. Once on the extracellular side of the membrane, ATP either follows a degradative pathway (2) or stimulates P2 receptors (3). In the first case, ATP, through the activity of the CD39 and CD73 enzymes, is transformed into adenosine (ADO), activating P1 $\left(\mathrm{A}_{1}, \mathrm{~A}_{2 \mathrm{~A}}, \mathrm{~A}_{2 \mathrm{~B}}\right.$, and $\left.\mathrm{A}_{3}\right)$ receptors. ADO can also be transported into the cell by ENT1 and ENT2 proteins or be inactivated to inosine (Ino) by CD26.

Adenosine activates four G-protein coupled receptors, $A_{1}, A_{2 A}, A_{2 B}$, and $A_{3}$, which are present on a wide range of cellular types, including both neuronal and glial cells [38]. This nucleoside acts as a neuromodulator in the brain, regulating a wide number of physiological effects relevant to AD pathology, spanning from sleep, cognitive abilities, and memory essentially to a control of excitatory synaptic stimulation through inhibitory effects that are mediated by $A_{1}$ receptors and synaptic plasticity induced by $A_{2 A}$ receptors [39]. The involvement of $\mathrm{A}_{1}$ receptors in $\mathrm{AD}$ has been investigated, and it was found that its activation may induce TAU phosphorylation and translocation towards cytoskeleton, possibly avoiding a tangle formation [40]. In addition, its effect on the increase in soluble $A \beta$ has been detected, suggesting a protective role for $A_{1}$ agonists [41]. On the other hand, it has been reported that a fat-enriched diet induced cognitive and memory dysfunctions as well as a reduction in the $A_{1}$ hippocampal receptors that were reverted by the $A_{1}$ receptor's antagonist, theobromine [42]. 
As for the $A_{2 B}$ and $A_{3}$ receptors, due to their effects on the central nervous system, they may be interesting targets for future investigations. Specifically, it has very recently been found that $A_{2 B}$ stimulation reduced the $A \beta$-dependent cognitive damage in $A D$-like animals by reducing the $A \beta$ accumulation, cholinergic dysfunction, and mitochondrial toxicity through MAPK activation [43]. Accordingly, a reduction in the $\mathrm{A}_{2 \mathrm{~B}}$ receptor expression in selected brain regions was observed in $A D$, suggesting that $A_{2 B}$ could be another therapeutic target of the pathology [44].

The $\mathrm{A}_{3}$ receptor in the brain is generally present at low levels in various cerebral regions, comprising of the hippocampus and cortex, and its activation reduced neuropathic pain through $\mathrm{N}$-type $\mathrm{Ca}^{2+}$ channel modulation [45-47]. In addition, its activation reduced inducible nitric oxide synthase (iNOS) expression, microglia migration, and phagocytosis in BV-2 cells that were stimulated using elevated hydrostatic pressure [48]. Accordingly, contrasting neuroinflammation decreases early brain damage dependent on subarachnoid hemorrhage in elderly animals [49].

$\mathrm{A}_{3}$ has also been found to reduce secondary tissue injury and cognitive damage in an animal model of traumatic brain injury [50].

However, among the adenosine receptors, the $\mathrm{A}_{2 \mathrm{~A}}$ subtype, which has already been a drug target for Parkinson's disease (PD) for a long time, is also the one receiving more attention as a therapeutic target in $\mathrm{AD}$ [51]. As for its expression, it is particularly abundant in striatal neurons, but it is also present in other areas of the CNS, such as the cortex and hippocampus, where they are located in the synapses and glia [52-54]. The effect of its neuronal activation is glutamate release, with consequent NMDA mGluR5-dependent stimulation and a postsynaptic calcium increase, which is responsible for synaptic changes and memory impairment $[55,56]$. Specifically, the hippocampus is the most important region of the brain for new learning and episodic/spatial memory, where the adult neurogenesis process occurs, limited to the dentate gyrus and the olfactory bulb sub-ventricular zone. Interestingly, through gene analysis studies, $A D O R A 2 A$ is significantly associated with hippocampal volume and the presence of its minor allele rs9608282-T, which is responsible for a reduction in its expression, is associated with better memory and a larger hippocampal volume, suggesting that an upsurge of $\mathrm{A}_{2 \mathrm{~A}}$ receptor levels in the cortex and hippocampus causes synaptic toxicity and memory deficits [57]. Accordingly, a rapid $A_{2 A}$ upregulation within the glutamatergic synapses increases the excitotoxicity through an NMDA receptor recruitment and excessive calcium influx, activating calpains and thus inducing neurodegeneration through mechanisms where glia cells are likely to participate [58].

Indeed, the occurrence of memory impairment in AD is not attributable to a generic neuronal loss, but is linked to the damage of functional synapses, in particular in the hippocampal region at the glutamatergic level [59-61]. Adenosine, generated by the ecto$5^{\prime}$-nucleotidase (CD73) enzyme, in animals with early AD, is responsible for the decrease in synaptic markers as wells as for memory damage and LTP disorders through the activation of the $A_{2 A}$ adenosine receptor $[39,60,61]$.

Interestingly, the $\mathrm{A}_{2 \mathrm{~A}}$ receptor is upregulated in the frontal cortex and hippocampus of elderly animals or in the presence of mutations causing AD as well as in humans affected by $\mathrm{AD}[39,56,62-69]$. The upregulation of neuronal $\mathrm{A}_{2 \mathrm{~A}}$ adenosine receptors in APP/PS1 mice impairs long-term synaptic potentiation (LTP) in CA3 pyramidal cells of the hippocampus, affecting their early synaptic deficit [70]. A wide body of literature reports that antagonism of $\mathrm{A}_{2 \mathrm{~A}}$ receptors at a synaptic level is responsible for neuroprotection, preventing memory damage in various AD animal models [71]. Specifically, the pharmacological approach of $A_{2 A}$ receptor blockade inhibits synaptic injury and cognitive disabilities in animals treated with $A \beta$, indicating that $A_{2 A}$ receptor blockers offer the opportunity to decrease synaptotoxicity and memory impairment [72-74]. The same approach restored memory and plasticity in the triple transgenic mouse model of $\mathrm{AD}$, expressing all three pathological hallmarks of AD, characterized by three cumulative mutations in TauP301L, APPSe, and $\gamma$-secretase (PS1M146V), that mimicked several features of AD, including the early memory deficits [61]. Similarly, the antagonism of $\mathrm{A}_{2 \mathrm{~A}}$ adenosine receptors using 
both gene silencing and pharmacological block in THY-TAU22 mice, ameliorates the TAU pathological phenotype by decreasing TAU hyperphosphorylation and aggregation, inflammation in the hippocampal region and, at the same time, saving spatial memory and hippocampal long-term depression [75]. The involvement of $\mathrm{A}_{2 \mathrm{~A}}$ receptor upregulation in tauopathy, TAU hyperphosphorylation, and memory damage was confirmed in a more recent study [76].

Several studies have revealed a role of the $\mathrm{A}_{2 \mathrm{~A}}$ receptor as a druggable protein in $\mathrm{AD}$, not only in neurons but also in microglia, to restore memory impairment and counteract neurodegenerative processes [71-77]. In this context, it is known that the essential role of the $\mathrm{A}_{2 \mathrm{~A}}$ adenosine receptor is the regulation of glial cell functions, addressing cytokine release, and thus inducing neuroinflammation [78]. Among glial cells, microglia are particularly important due to the increase in $\mathrm{A}_{2 \mathrm{~A}}$ receptor expression in activated cells that are located near the amyloid plaques that are typical of AD. Overexpression of this adenosine receptor subtype induces an increase in cytokines, including IL-1 $\beta$, IL-6, and TNF- $\alpha$, while its blockade hampers hippocampal LTP disorders and IL-1 $\beta$ secretion, playing a key role to decrease the memory deficit $[79,80]$. The upregulation of $A_{2 A}$ receptors that occur in microglia also expressing NMDA receptors is also of interest [81]. Specifically, it has been shown that they may form, both in neurons and microglia, $\mathrm{A}_{2 \mathrm{~A}}$-NMDA heteromers, interacting in a reciprocal way, where $A_{2 A}$ receptor blockers antagonize an NMDA-dependent calcium increase [56,81-83]. Of particular relevance in microglia is the presence of $\mathrm{A}_{2 \mathrm{~A}^{-}}$ $\mathrm{CB}_{2}$ heteromers, upregulated in $\mathrm{AD}$, where $\mathrm{A}_{2 \mathrm{~A}}$ receptor antagonists are responsible for the increase in $\mathrm{CB}_{2}$ receptor activity, thus potentiating the neuroprotection mediated by endocannabinoids [79-81] (Table 1).

Table 1. Purinergic mediated responses and role in AD of P1 and P2 receptors expressed in neuronal, astrocytic, and microglial cells.

\begin{tabular}{|c|c|c|c|c|}
\hline Purinergic Receptor & Cell Type & Response & Role in AD & Refrerences \\
\hline \multirow[t]{2}{*}{ A1 } & Neuron & TAU translocation & positive & [36] \\
\hline & & Non-Am. APP Processing & Positive & {$[36]$} \\
\hline \multirow[t]{6}{*}{$\mathrm{A}_{2 \mathrm{~A}}$} & Neuron & A $\beta$-Induced Neurotoxiciy & Negative & {$[54,59,60,66,68,69]$} \\
\hline & Neuron & Increased $A \beta$ accumulation & Negative & {$[84,85]$} \\
\hline & Neuron & Tau pathology & Negative & {$[71,72]$} \\
\hline & Neuron & Memory damage & Negative & {$[84]$} \\
\hline & Astrocytes & Memory function & Negative & [62] \\
\hline & Microglia & Neuroinflammation & Negative & {$[75,76]$} \\
\hline $\mathrm{A}_{2 \mathrm{~B}}$ & Neuron & Mitochondrial function & Positive & {$[39,40]$} \\
\hline $\mathrm{A}_{3}$ & Microglia & Decrease of inflammation & Positive & {$[44]$} \\
\hline $\mathrm{P} 2 \mathrm{X} 4$ & Neuron & Neurotoxicity & Negative & {$[86,87]$} \\
\hline \multirow[t]{2}{*}{$\mathrm{P} 2 \mathrm{X7}$} & Microglia & Inflammation & Negative & [88-94] \\
\hline & Neuron & Amyloidogenic & Negative & [95-97] \\
\hline \multirow[t]{2}{*}{$\mathrm{P}_{2} \mathrm{Y}_{1}$} & Astrocyte & Hyper-Activation & Negative & {$[98]$} \\
\hline & Neuron & Synaptic damage & Negative & [98] \\
\hline \multirow[t]{2}{*}{$\mathrm{P}_{2} \mathrm{Y}_{2}$} & Neuron & Neurite Development & Positive & [95] \\
\hline & Neuron & Non-Am. APP Processing & Positive & [99] \\
\hline $\mathrm{P}_{2} \mathrm{Y}_{4}$ & Microglia & Uptake $A \beta_{1-42}$ & Positive & [100] \\
\hline $\mathrm{P}_{2} \mathrm{Y}_{6}$ & Microglia & Phagocytosis & Positive & [86] \\
\hline $\mathrm{P}_{2} \mathrm{Y}_{12}$ & Microglia & Migration & Positive & {$[101]$} \\
\hline $\mathrm{P}_{2} \mathrm{Y}_{13}$ & Neuron & Decrease ROS-induced death & Positive & [102] \\
\hline
\end{tabular}


The clinical relevance of $\mathrm{A}_{2 \mathrm{~A}}$ adenosine antagonists to avoid memory impairment is attested by human studies demonstrating the efficacy of caffeine intake in the prevention of cognitive dysfunction in the elderly [103-111]. Indeed caffeine, the most widely consumed psychostimulant substance, present in coffee, tea, cola, chocolate, and other foods, behaves essentially as a blocker of $\mathrm{A}_{2 \mathrm{~A}}$ receptors in the brain [112-114]. Accordingly, a 20-year retrospective study devoted to revealing whether caffeine intake could protect against AD demonstrated an inverse correlation between coffee consumption and disease development [115]. In addition, a five-year prospective analysis of the Canadian population investigating the consequence of daily coffee consumption on AD progression indicated an odds ratio of 0.69 that is suggestive of a significant reduction in AD risk [116]. In particular, an intake of three cups of coffee per day was inversely related to a decrease in cognitive function [117,118]. Accordingly, an intake of 3-5 cups of coffee/day decreased the risk of dementia and AD by $65-70 \%$ and $62-64 \%$, respectively, versus a minor consumption [103]. Further studies reported that patients affected by MCI, who later progressed to dementia, presented lower plasma levels of caffeine in comparison to stable MCI patients during a period of 2-4 years [119]. Interestingly, it has been suggested that caffeinated coffee consumption was associated with this protection probably hampering a specific immune deficit linked to a decrease in G-CSF, IL-10, and IL-6 levels in MCI patients several years prior to dementia conversion [119]. In particular, as for G-CSF, it affects synaptogenesis, neurogenesis, and $A \beta$ cerebral phagocytosis by immune cells, thus providing cognitive improvement in AD mice [119]. Accordingly, a recent clinical trial with sargramostim, a recombinant GM-CSF, found an increase in activated microglia, a 50\% decrease in amyloid content, a rise in the synaptic area, and an amelioration in spatial memory [120]. Indeed, its blood levels, together with that of other neurotrophic/hematopoietic factors (e.g., BDNF, SCF), have been found to be reduced in early AD [121], resulting in deficient neurotrophic/hematopoietic brain support. The role of the immune system and inflammation is quite complex; when microglial cells are moderately activated and specifically induced to remove an amyloid (immunomodulatory, monoclonal-Ab, and active immunization treatments), the effect can be favorable. Unfortunately, in the elderly, immunological senescence and "inflammaging" chronic phenomena lead to an excessive inflammatory activation and a reduction in the specific adaptive responses of the immune system. Therefore, the loss of balance in the processes of immunity and inflammation, especially in old age, results in damage [84,85,122,123].

Further studies confirmed the beneficial effects of caffeine consumption in humans, with the lack of dementia and cerebral damage typical of AD, and to a rise in long-term memory consolidation $[105,124,125]$. Furthermore, the administration of caffeine to animals with AD revealed a lower risk of memory disabilities, and less beta-amyloid accumulation and TAU hyperphosphorylation [104,108,126-132], whilst in SH-SY5Y cells antioxidant and anti-inflammatory properties have been detected $[133,134]$. However, it has to be underlined that coffee contains caffeine as well as more than 2000 other substances that may have biological activities. At this proposal, it has been reported that the CSF levels of theobromine, a metabolite of caffeine, in demented patients or its intake through chocolate is inversely correlated with memory disabilities $[135,136]$.

The neuroprotection exerted by caffeine is not a novelty, as there is a huge amount of literature reporting that an $\mathrm{A}_{2 \mathrm{~A}}$ adenosine receptor block is also beneficial in the case of $\mathrm{PD}$, where istradefylline, an $\mathrm{A}_{2 \mathrm{~A}}$ adenosine receptor antagonist, has been launched as a new drug for the treatment of this disease in Japan (Nouriast) and in the US (Nourianz) due to its safety and efficacy $[38,137,138]$. On these bases, it would be important that future studies also establish its efficacy in the reduction in memory impairment in patients with AD [74]. This evidence would allow for a rapid entry of this drug on the market for AD treatment. 


\section{ATP and AD}

Membrane receptors for the extracellular nucleotides are widely distributed in eukaryotic cells. They are activated by nucleotides such as ATP, ADP, UTP, UDP, etc., which are released from the cells or synthesized extracellularly, where they bind to ionotropic P2X and G-protein-coupled P2Y receptors. Seven P2X receptor genes have been identified in humans, while there are eight for P2Y receptors. P2X subunits can assemble as homo- or hetero-oligomers, and ATP is an agonist for all of the P2X subtypes.

P2Y receptors are seven domain membrane-spanning molecules that bind to Gproteins and show different ligand affinities for uridine and adenine nucleotides. According to their gene sequence, G-protein coupling, and agonist affinity, they are divided into two subgroups. One includes the $\mathrm{P}_{2} \mathrm{Y}_{1}, \mathrm{P}_{2} \mathrm{Y}_{2}, \mathrm{P}_{2} \mathrm{Y}_{4}, \mathrm{P}_{2} \mathrm{Y}_{6}$, and $\mathrm{P}_{2} \mathrm{Y}_{11}$ receptors, while the other comprises of the $\mathrm{P}_{2} \mathrm{Y}_{12}, \mathrm{P}_{2} \mathrm{Y}_{13}$, and $\mathrm{P}_{2} \mathrm{Y}_{14}$ subtypes. Gq/G11 proteins couple to the first receptors, whose activation generates inositol-1,4,5-triphosphate and evokes $\mathrm{a} \mathrm{Ca}^{2+}$ liberation from the endoplasmic reticulum. The latter receptors couple to Gi/G0 proteins, causing adenylyl cyclase inhibition [139]. A plethora of scientific reports have documented the multiple effects of P2 receptors in human tissues [140]. Concerning the central nervous system (CNS), neuronal cells express P2X and P2Y receptors particularly of the following subtypes: P2X2, P2X4, P2X4/P2X6, and P2Y [141]. In neuronal cells, P2 localization can be pre- or postsynaptic. Differences exist between pre-synaptic expression of the P2X and P2Y receptors, that may be either excitatory (P2X) or inhibitory (P2Y), while post-synaptic $\mathrm{P} 2$ subtypes are always excitatory [141]. In the CNS, microglial cells also express different $\mathrm{P} 2$ subtypes (P2X4, $\mathrm{P} 2 \mathrm{X} 7, \mathrm{P}_{2} \mathrm{Y}_{6}$, and $\mathrm{P} 2 \mathrm{Y}_{12}$ ) that are able to profoundly modulate responses, particularly those that are linked to inflammation [88-90]. Astrocytes also express P2 receptors that are involved in their activation and in the release of cell factors promoting neuronal damage repair and axonal regeneration [142]. Different P2X subtypes have been linked to pain perception, among them, the neuronal P2X3, P2X2/P2X3 heterotrimers, and microglial P2X4 receptor [143].

The P2X7 subtype has attracted a lot of interest among immunologists as it is widely expressed in cells of the innate immune system and has an ability to modulate the immune response. Among the cells expressing high levels of this subtype are macrophages, microglia, dendritic cells, but also B and T lymphocytes. Moreover, it is present in different regions of the CNS, i.e., the frontal cortex, hippocampus, amygdala, and striatum, making it an interesting molecule to bridge neuroimmune response and brain dysfunction [144]. Hence, P2X7 activation has been implicated in pathological neuroinflammation, neuronal damage, and death [145]. Moreover, a number of influential studies have linked P2X7 to neuropsychiatric disorders and diseases. In particular, receptor single nucleotide polymorphisms have been associated with anxiety, bipolar disorder, depression, multiple sclerosis, Parkinson's, and Alzheimer's disease [144,146].

The formation of $A \beta$ plaques and neuronal cell deaths are hallmarks of $\mathrm{AD}$ [147] and, as shown in the mouse model, both $\mathrm{A} \beta$ and its precursor are potent neuroinflammatory stimuli heavily compromising blood circulation in the brain. However, quite a recent and important acquisition in understanding the pathogenesis of $\mathrm{AD}$ has consisted of the identification of co-inflammatory agents that are able to increase the deleterious effects of A $\beta$. Extracellular ATP can burst inflammation and cause neuronal damage by activating the P2 receptors expressed by microglia, astrocytes, and neuronal cells [148]. From a mechanistic point of view, it can be hypothesized that the activation of the P2X receptors may cause neuronal stress and death due to excessive $\mathrm{Ca}^{2+}$ entry increasing the cytoplasmic $\mathrm{Ca}^{2+}$ concentration and causing mitochondrial $\mathrm{Ca}^{2+}$ overload, up to levels that undermine the activity of the organelles, with a formation of radical species and the release of pro-apoptotic factors. An accumulation of $A \beta$ also increases the intracellular $\mathrm{Ca}^{2+}$ in neurons, both by causing an external $\mathrm{Ca}^{2+}$ influx and a release of the ion from the intracellular stores. Excessive long-term depression causing progressive memory decline and increased neuronal apoptosis in $\mathrm{AD}$ patients has been hypothesized to depend on an upregulation of $\mathrm{Ca}^{2+}$ signaling [149]. Moreover, the $\mathrm{A} \beta_{25-35}$ fragment evokes intracellular 
$\mathrm{Ca}^{2+}$ concentration changes via connexin hemichannel opening and purinergic receptor activation in astrocytes, whose exposure to $\mathrm{A} \beta_{25-35}$ induces both a $\mathrm{Ca}^{2+}$-independent and $\mathrm{Ca}^{2+}$-dependent glutamate release in the brain of the hAPPJ20 AD mouse model [150].

Microglia were found to be particularly important for the setting of the inflammatory background underlying $A D$ as $A \beta$ induces an ATP release from these cells and activates them to migrate towards the plaques. Moreover, ATP-stimulated microglia release inflammatory cytokines and toxic mediators, contributing to the neuronal cell death that is evident in AD [91-93].

Different P2 receptors play a role in inflammation. Among them, it is long known the fundamental role of the P2X7 subtype in bursting and sustaining both sterile and non-sterile inflammation [94]. Since AD has been interpreted as a pathological modification of the central nervous system due to a chronic inflammatory status, investigations have increasingly concentrated on P2X7. Expression of the receptor was found increased in an AD mouse model, the P301C TAU transgenic mice [151], as well as upon the intrahippocampal injection of A $\beta$ in Tg2576 transgenic mice and rats [152]. Similarly, P2X7 upregulation is present in the brain tissue of $\mathrm{AD}$ patients, and molecular modifications of the subtype have been also described, although their significance has not yet been interpreted $[153,154]$. Another peculiarity of the $\mathrm{P} 2 \mathrm{X} 7$ receptor expressed in AD patients is the presence of two SNPs, i.e., the 1513A > C (rs3751143) and 489C > T (rs208294). The contemporary presence of these modifications would contribute to the disease pathogenesis [155].

The functional involvement of P2X7 in AD has been intensively investigated and different responses mediated by the receptor have been linked to the tissue modifications found in AD animal models and in humans. The involvement of P2X7 in the secretion and cleavage of pro-IL-1 $\beta$ in macrophages and microglia have been widely documented in different systems and with various experimental setups [156]. Accordingly, the intracellular pro-IL-1 $\beta$ of the $\mathrm{P} 2 \mathrm{X}^{-/-}$mouse macrophages is not activated by caspase- 1 and externalized [157]. Moreover, general in vivo inflammatory response and leukocyte activity is less pronounced in animals lacking the receptor [95]. It is of particular interest for AD pathogenesis, as the activation of microglia by $\mathrm{A} \beta$ requires $\mathrm{P} 2 \mathrm{X} 7$ expression [93]. Accordingly, P2X7 pharmacologic inhibition obliterates $A \beta$-induced microglial activation [96]. Mechanistically, $\mathrm{A} \beta$ evokes the liberation of intracellular ATP that, in turn, causes the release of the pro-inflammatory cytokines IL- $1 \beta$, TNF- $\alpha$, IL-18, and IL-6 in rat and mouse microglia $[86,87,97]$. Interestingly, these cytokines have been indicated as crucial molecules in $\mathrm{AD}$ and their concentration is increased in AD patients' brains [98-100]. Another recently identified P2X7-related pathway leading to pathogenic consequences is that involving CCL3 chemokine secretion in an AD mouse model. In this study, the authors showed that $\mathrm{A} \beta$ stimulated a $\mathrm{CD} 8^{+}$lymphocyte recruitment [101]. Moreover, an $\mathrm{A} \beta$ peptide increases $\mathrm{P} 2 \mathrm{X} 7$ expression in microglia and a rat's hippocampus, and activation of the subtype causes neuronal apoptosis $[158,159]$. P2X7 receptor activation has been also linked to the secretion of APP fragments in different experimental models. In particular, the receptor caused the formation of non-amyloidogenic APP by metalloproteases [160]. The process was totally dependent on P2X7 receptor expression and was absent in P2X7-/-cells. Moreover, the fact that $\operatorname{APP} \alpha$, and not $\mathrm{A} \beta$, fragments were found upon activation of $\mathrm{P} 2 \mathrm{X} 7$ has prompted researchers to hypothesize that the $\alpha$-secretase pathway was mainly stimulated by the receptor. However, different studies have produced contrasting results, i.e., the prevention of $\alpha$-secretase activity by P2X7 activation [161-163] (Table 1 ).

Less information is available on the involvement of the P2X2 subtype in AD. A pretreatment of PC12 cells and hippocampal neurons with an A $\beta$-increased P2X2 expression and ATP induced a $\mathrm{Ca}^{2+}$ increase [164]. P2X4 stimulation would augment $\mathrm{A} \beta_{1-42-}$ mediated toxic effects, making it also a potential pharmacologically targetable molecule for AD $[165,166]$.

$\mathrm{P} 2 \mathrm{Y}$ receptors have also been linked to $\mathrm{AD}$, although their signaling and role have not been completely characterized in AD tissues. So far, the majority of P2Y-mediated responses appear to be neuroprotective and even able to prevent $A \beta$ deleterious effects, 
with the exception of the $\mathrm{P}_{2} \mathrm{Y}_{1}$ subtype $[161,167,168]$. This subtype is highly expressed in the reactive astrocytes surrounding plaques and was found responsible for causing astrocytic hyperactivity in APPPS1 mice, a mouse model of AD. Accordingly, inhibition of the $\mathrm{P}_{2} \mathrm{Y}_{1}$ receptor normalized the astroglial network dysfunction [169].

$\mathrm{P}_{2} \mathrm{Y}_{1}, \mathrm{P}_{2} \mathrm{Y}_{2}, \mathrm{P}_{2} \mathrm{Y}_{4}, \mathrm{P}_{2} \mathrm{Y}_{6}$, and $\mathrm{P} 2 \mathrm{Y}_{12}$ receptors seem more involved in brain changes found in AD. P2 $Y_{1}$ is involved in astrocyte hyperreactivity and its inhibition reduces neuronal damage and synaptic dysfunction, thus preserving spatial learning and memory, in mice [168]. The $\mathrm{P} 2 \mathrm{Y}_{2}$ subtype stimulates the degradation and uptake of $\mathrm{A} \beta_{1-42}$ [170], with $\mathrm{P} \mathrm{Y}_{4}$ playing a similar role [171], while $\mathrm{P}_{2} \mathrm{Y}_{6}$ and $\mathrm{P} 2 \mathrm{Y}_{12}$ would be involved in modulating the removal of dead neurons by the microglia [165-172].

\section{Conclusions}

Different approaches have been tested to treat AD. Trials using pharmacological drugs that aimed to lower levels of $A \beta$ and prevent its deleterious accumulation in the brain have unfortunately been unsatisfactory; therefore, alternative strategies have to be taken into account.

Coffee, the most consumed beverage in the world, contains caffeine, a famous psychoactive substance that, following regular consumption, is associated with a reduction in $\mathrm{AD}$ insurgence in humans. Its mechanism of action is linked to an interaction with the $\mathrm{A}_{2 \mathrm{~A}}$ adenosine receptor, whose level of expression and transduction machinery is deeply modified in the aged hippocampus, where it undergoes overactivation, leading to an increase in glutamate synapsis functioning, with mGluR5-dependent NMDA receptor overstimulation, leading to a calcium overload that is a typical hallmark of aging. Several works agree to indicate, either by antagonizing $\mathrm{A}_{2 \mathrm{~A}}$ or silencing it, that its removal is responsible for beneficial effects in both aged and animal AD models [173]. Even though further work is necessary to clarify all the aspects related to the effects of $A_{2 A}$ receptor antagonism in $\mathrm{AD}$, the premise regarding its capability to affect synaptotoxicity, glutamate transmission, calcium overload, as well as neuroinflammation, are encouraging and suggest a key role for its antagonism as a novel approach to avoid AD insurgence.

Another likely practicable approach may be to counteract neuroinflammation, whose signs (microglial activation and the presence of inflammatory cytokines) have been found in post-mortem samples of AD patients' brains [172]. Since the P2X7 receptor plays a pivotal role in inflammation, different clinical trials have been undertaken in humans with specific inhibitors of this subtype. They are all aimed at treating diseases where chronic inflammation plays a prominent role [174]. Antagonists of the P2X7 receptors are obviously also good candidates to counteract the dangerous effects of chronic brain inflammation and pathological responses arising in the central nervous system [175]. The intense research on these molecules has contributed to the development of selective and effective pharmacological inhibitors. Some of them are also endowed with the ability to pass the hematoencephalic barrier, thus permeating the cerebral tissue $[102,176,177]$.

Inhibition of the P2X7 receptor to block its proinflammatory effects on $A \beta$ has been questioned by some authors that found spatial memory impairment and the alteration of other behavioral parameters in $\mathrm{P} 2 \mathrm{X}^{-/-}$mice and in animals in which P2X7 was pharmacologically inhibited. It has to be said that these results were obtained in AD animal models and, so far, no one can predict the consequences of P2X7 antagonization in the human brain $[102,178,179]$.

Brilliant blue $\mathrm{G}$ (BBG), which has been widely used in in vitro experiments as an effective P2X7 blocker, crosses the blood-brain barrier, therefore, it was also employed in vivo animal experiments with positive results [180]. Among recently developed P2X7 targeting molecules, we can mention compounds that are going to be tested in different animal models, i.e., CE-224535 by Pfizer, GSK1370319A and GSK1482160 by GlaxoSmithKline, and JNJ-54175446 and JNJ-55308942 by Janssen laboratories [175,181-187]. The P2Y 1 subtype seems to be a good candidate to normalize the astrocyte hyperactivity, glio-vascular 
signaling, and overall neuronal functionality as in vivo experiments with blockers of the receptors showed very positive results in a mouse model of AD [169].

Another strategy involving nucleotides and their pharmacological analogues as potential pharmacological molecules in AD has taken into account the oxidative stress characteristic of the disease $[174,175]$. ATP- $\gamma-S$, the non-hydrolysable ATP analog, is a recognized P2 receptor agonist but is also an antioxidant with neuroprotective properties. The chemical modification of this molecule has further increased its antioxidant capacity and stability, making it very interesting to try to reduce neuronal mortality [188-191]. Hence, both adenosine- and ATP-mediated purinergic signaling seem to be promising ways to treat AD.

Author Contributions: S.M., T.E.P., A.T., E.M., S.G. and D.F. wrote the paper. All authors have read and agreed to the published version of the manuscript.

Funding: D.F. received local funds from the University of Ferrara.

Institutional Review Board Statement: Not applicable.

Informed Consent Statement: Not applicable.

Conflicts of Interest: The authors declare that the research was conducted in the absence of any commercial or financial relationships that could be construed as a potential conflict of interest.

\section{References}

1. American Psychiatric Association. Diagnostic and Statistical Manual of Mental Disorders: DSM-5, 5th ed.; American Psychiatric Publishing: Arlinghton, VA, USA, 2013.

2. Sachdev, P.S.; Mohan, A.; Taylor, L.; Jeste, D.V. DSM-5 and mental disorders in older individuals: An overview. Harv. Rev. Psychiatry 2015, 23, 320-328. [CrossRef] [PubMed]

3. Hanseeuw, B.J.; Betensky, R.A.; Jacobs, H.I.L.; Schultz, A.P.; Sepulcre, J.; Becker, J.A.; Cosio, D.M.O.; Farrell, M.; Quiroz, Y.T.; Mormino, E.C.; et al. Association of Amyloid and Tau With Cognition in Preclinical Alzheimer Disease: A Longitudinal Study. JAMA Neurol. 2019, 76, 915-924. [CrossRef]

4. Elahi, F.M.; Miller, B.L. A clinicopathological approach to the diagnosis of dementia. Nat. Rev. Neurol. 2017, 13, 457-476. [CrossRef] [PubMed]

5. Sepulveda, F.J.; Parodi, J.; Peoples, R.W.; Opazo, C.; Aguayo, L.G. Synaptotoxicity of Alzheimer Beta Amyloid Can Be Explained by Its Membrane Perforating Property. PLoS ONE 2010, 5, e11820. [CrossRef] [PubMed]

6. Kandel, N.; Matos, J.O.; Tatulian, S.A. Structure of amyloid $\beta 25-35$ in lipid environment and cholesterol-dependent membrane pore formation. Sci. Rep. 2019, 9, 2689. [CrossRef]

7. Nortley, R.; Korte, N.; Izquierdo, P.; Hirunpattarasilp, C.; Mishra, A.; Jaunmuktane, Z.; Kyrargyri, V.; Pfeiffer, T.; Khennouf, L.; Madry, C.; et al. Amyloid $\beta$ oligomers constrict human capillaries in Alzheimer's disease via signaling to pericytes. Science 2019, 365, eaav9518. [CrossRef] [PubMed]

8. Selkoe, D.J.; Hardy, J. The amyloid hypothesis of Alzheimer's disease at 25 years. EMBO Mol. Med. 2016, 8, 595-608. [CrossRef]

9. Jack, C.R.; Wiste, H.J.; Schwarz, C.G.; Lowe, V.J.; Senjem, M.L.; Vemuri, P.; Weigand, S.D.; Therneau, T.M.; Knopman, D.S.; Gunter, J.L.; et al. Longitudinal tau PET in ageing and Alzheimer's disease. Brain 2018, 141, 1517-1528. [CrossRef]

10. Perez-Nievas, B.G.; Stein, T.D.; Tai, H.-C.; Dols-Icardo, O.; Scotton, T.C.; Barroeta-Espar, I.; Fernandez-Carballo, L.; De Munain, E.L.; Perez, J.; Marquie, M.; et al. Dissecting phenotypic traits linked to human resilience to Alzheimer's pathology. Brain 2013, 136, 2510-2526. [CrossRef]

11. Mirra, S.S.; Heyman, A.; McKeel, D.; Sumi, S.M.; Crain, B.J.; Brownlee, L.M.; Vogel, F.S.; Hughes, J.P.; Van Belle, G.; Berg, L.; et al. The Consortium to Establish a Registry for Alzheimer's Disease (CERAD): Part II. Standardization of the neuropathologic assessment of Alzheimer's disease. Neurology 1991, 41, 479-486. [CrossRef]

12. Braak, H.; Alafuzoff, I.; Arzberger, T.; Kretzschmar, H.; Del Tredici, K. Staging of Alzheimer disease-associated neurofibrillary pathology using paraffin sections and immunocytochemistry. Acta Neuropathol. 2006, 112, 389-404. [CrossRef] [PubMed]

13. Montine, T.J.; Phelps, C.H.; Beach, T.G.; Bigio, E.H.; Cairns, N.J.; Dickson, D.W.; Duyckaerts, C.; Frosch, M.P.; Masliah, E.; Mirra, S.S.; et al. National Institute on Aging-Alzheimer's Association guidelines for the neuropathologic assessment of Alzheimer's disease: A practical approach. Acta Neuropathol. 2011, 123, 1-11. [CrossRef]

14. Serrano-Pozo, A.; Betensky, R.A.; Frosch, M.P.; Hyman, B.T. Plaque-Associated Local Toxicity Increases over the Clinical Course of Alzheimer Disease. Am. J. Pathol. 2016, 186, 375-384. [CrossRef] [PubMed]

15. Ising, C.; Venegas, C.; Zhang, S.; Scheiblich, H.; Schmidt, S.V.; Vieira-Saecker, A.; Schwartz, S.; Albasset, S.; McManus, R.M.; Tejera, D.; et al. NLRP3 inflammasome activation drives tau pathology. Nature 2019, 575, 669-673. [CrossRef]

16. Völgyi, K.; Badics, K.; Sialana, F.J.; Gulyássy, P.; Udvari, E.B.; Kis, V.; Drahos, L.; Lubec, G.; Kékesi, K.A.; Juhász, G. Early Presymptomatic Changes in the Proteome of Mitochondria-Associated Membrane in the APP/PS1 Mouse Model of Alzheimer's Disease. Mol. Neurobiol. 2018, 55, 7839-7857. [CrossRef] 
17. Shoshan-Barmatz, V.; Nahon-Crystal, E.; Shteinfer-Kuzmine, A.; Gupta, R. VDAC1, mitochondrial dysfunction, and Alzheimer's disease. Pharmacol. Res. 2018, 131, 87-101. [CrossRef] [PubMed]

18. Jack, C.R., Jr.; Bennett, D.A.; Blennow, K.; Carrillo, M.C.; Dunn, B.; Haeberlein, S.B.; Holtzman, D.M.; Jagust, W.; Jessen, F.; Karlawish, J.; et al. NIA-AA Research Framework: Toward a biological definition of Alzheimer's disease. Alzheimer's Dement. 2018, 14, 535-562. [CrossRef] [PubMed]

19. Chételat, G.; Arbizu, J.; Barthel, H.; Garibotto, V.; Law, I.; Morbelli, S.; van de Giessen, E.; Agosta, F.; Barkhof, F.; Brooks, D.J.; et al. Amyloid-PET and 18F-FDG-PET in the diagnostic investigation of Alzheimer's disease and other dementias. Lancet Neurol. 2020, 19, 951-962. [CrossRef]

20. Dubois, B.; Hampel, H.; Feldman, H.H.; Scheltens, P.; Aisen, P.; Andrieu, S.; Bakardjian, H.; Benali, H.; Bertram, L.; Blennow, K.; et al. Preclinical Alzheimer's disease: Definition, natural history, and diagnostic criteria. Alzheimer's Dement. 2016, 12, 292-323. [CrossRef]

21. Molinuevo, J.L.; Ayton, S.; Batrla, R.; Bednar, M.M.; Bittner, T.; Cummings, J.; Fagan, A.M.; Hampel, H.; Mielke, M.M.; Mikulskis, A.; et al. Current state of Alzheimer's fluid biomarkers. Acta Neuropathol. 2018, 136, 821-853. [CrossRef]

22. Lewczuk, P.; Ermann, N.; Andreasson, U.; Schultheis, C.; Podhorna, J.; Spitzer, P.; Maler, J.M.; Kornhuber, J.; Blennow, K.; Zetterberg, H. Plasma neurofilament light as a potential biomarker of neurodegeneration in Alzheimer's disease. Alzheimer's Res. Ther. 2018, 10, 71. [CrossRef] [PubMed]

23. Vermunt, L.; Sikkes, S.A.; Hout, A.V.D.; Handels, R.; Bos, I.; Van Der Flier, W.M.; Kern, S.; Ousset, P.-J.; Maruff, P.; Skoog, I.; et al. Duration of preclinical, prodromal, and dementia stages of Alzheimer's disease in relation to age, sex, and APOE genotype. Alzheimer's Dement. 2019, 15, 888-898. [CrossRef] [PubMed]

24. Williamson, J.; Goldman, J.; Marder, K.S. Genetic Aspects of Alzheimer Disease. Neurologist 2009, 15, 80-86. [CrossRef] [PubMed]

25. Livingston, J.M.; McDonald, M.W.; Gagnon, T.; Jeffers, M.S.; Gomez-Smith, M.; Antonescu, S.; Cron, G.O.; Boisvert, C.; Lacoste, B.; Corbett, D. Influence of metabolic syndrome on cerebral perfusion and cognition. Neurobiol. Dis. 2020, 137, 104756. [CrossRef] [PubMed]

26. Lourida, I.; Hannon, E.; Littlejohns, T.J.; Langa, K.M.; Hyppönen, E.; Kuzma, E.; Llewellyn, D.J. Association of Lifestyle and Genetic Risk With Incidence of Dementia. JAMA 2019, 322, 430-437. [CrossRef] [PubMed]

27. Cummings, J.; Lee, G.; Ritter, A.; Sabbagh, M.; Zhong, K. Alzheimer's disease drug development pipeline: 2020. Alzheimer's Dement. Transl. Res. Clin. Interv. 2020, 6, e12050. [CrossRef]

28. Bittar, A.; Bhatt, N.; Kayed, R. Advances and considerations in AD tau-targeted immunotherapy. Neurobiol. Dis. 2020, 134, 104707. [CrossRef]

29. Hara, Y.; McKeehan, N.; Fillit, H.M. Translating the biology of aging into novel therapeutics for Alzheimer disease. Neurology 2019, 92, 84-93. [CrossRef]

30. Cummings, J.L.; Cohen, S.; Van Dyck, C.H.; Brody, M.; Curtis, C.; Cho, W.; Ward, M.; Friesenhahn, M.; Rabe, C.; Brunstein, F.; et al. ABBY. Neurology 2018, 90, e1889-e1897. [CrossRef]

31. Sperling, R.A.; Jack, C.R.; Aisen, P.S. Testing the Right Target and Right Drug at the Right Stage. Sci. Transl. Med. 2011, 3 , $111 \mathrm{~cm} 33$. [CrossRef]

32. Long, J.M.; Holtzman, D.M. Alzheimer Disease: An Update on Pathobiology and Treatment Strategies. Cell 2019, 179, 312-339. [CrossRef] [PubMed]

33. Poloni, T.E.; Medici, V.; Carlos, A.F.; Davin, A.; Ceretti, A.; Mangieri, M.; Cassini, P.; Vaccaro, R.; Zaccaria, D.; Abbondanza, S.; et al. Abbiategrasso Brain Bank Protocol for Collecting, Processing and Characterizing Aging Brains. J. Vis. Exp. 2020, $160,60296$. [CrossRef] [PubMed]

34. Newby, A.C. Adenosine and the concept of 'retaliatory metabolites'. Trends Biochem. Sci. 1984, 9, 42-44. [CrossRef]

35. Drury, A.N.; Szent-Györgyi, A. The physiological activity of adenine compounds with especial reference to their action upon the mammalian heart1. J. Physiol. 1929, 68, 213-237. [CrossRef] [PubMed]

36. Ballesteros-Yáñez, I.; Castillo, C.A.; Merighi, S.; Gessi, S. The Role of Adenosine Receptors in Psychostimulant Addiction. Front. Pharmacol. 2018, 8, 985. [CrossRef] [PubMed]

37. Borea, P.A.; Gessi, S.; Merighi, S.; Varani, K. Adenosine as a Multi-Signalling Guardian Angel in Human Diseases: When, Where and How Does it Exert its Protective Effects? Trends Pharmacol. Sci. 2016, 37, 419-434. [CrossRef]

38. Borea, P.A.; Gessi, S.; Merighi, S.; Vincenzi, F.; Varani, K. Pharmacology of Adenosine Receptors: The State of the Art. Physiol. Rev. 2018, 98, 1591-1625. [CrossRef]

39. Gonçalves, F.Q.; Lopes, J.P.; Silva, H.B.; Lemos, C.; Silva, A.C.; Gonçalves, N.; Tomé, Â.R.; Ferreira, S.; Canas, P.M.; Rial, D.; et al. Synaptic and memory dysfunction in a $\beta$-amyloid model of early Alzheimer's disease depends on increased formation of ATP-derived extracellular adenosine. Neurobiol. Dis. 2019, 132, 104570. [CrossRef]

40. Angulo, E.; Casadó, V.; Mallol, J.; Canela, E.I.; Viñals, F.; Ferrer, I.; Lluis, C.; Franco, R. A1 Adenosine Receptors Accumulate in Neurodegenerative Structures in Alzheimer's Disease and Mediate Both Amyloid Precursor Protein Processing and Tau Phosphorylation and Translocation. Brain Pathol. 2006, 13, 440-451. [CrossRef]

41. Cieślak, M.; Wojtczak, A. Role of purinergic receptors in the Alzheimer's disease. Purinergic Signal. 2018, 14, 331-344. [CrossRef]

42. Mendiola-Precoma, J.; Padilla, K.; Rodríguez-Cruz, A.; Berumen, L.C.; Miledi, R.; García-Alcocer, G. Theobromine-Induced Changes in A1 Purinergic Receptor Gene Expression and Distribution in a Rat Brain Alzheimer's Disease Model. J. Alzheimer's Dis. 2017, 55, 1273-1283. [CrossRef] 
43. Semwal, B.C.; Garabadu, D. 5-N-ethyl Carboxamidoadenosine Stimulates Adenosine-2b Receptor-Mediated Mitogen-Activated Protein Kinase Pathway to Improve Brain Mitochondrial Function in Amyloid Beta-Induced Cognitive Deficit Mice. NeuroMol. Med. 2020, 22, 542-556. [CrossRef]

44. Semwal, B.C.; Garabadu, D. Amyloid beta (1-42) downregulates adenosine-2b receptors in addition to mitochondrial impairment and cholinergic dysfunction in memory-sensitive mouse brain regions. J. Recept. Signal Transduct. 2020, 40, 531-540. [CrossRef]

45. Coppi, E.; Cherchi, F.; Fusco, I.; Failli, P.; Vona, A.; Dettori, I.; Gaviano, L.; Lucarini, E.; Jacobson, K.A.; Tosh, D.K.; et al. Adenosine A3 receptor activation inhibits pronociceptive $\mathrm{N}$-type $\mathrm{Ca} 2+$ currents and cell excitability in dorsal root ganglion neurons. Pain 2019, 160, 1103-1118. [CrossRef]

46. Lucarini, E.; Coppi, E.; Micheli, L.; Parisio, C.; Vona, A.; Cherchi, F.; Pugliese, A.M.; Pedata, F.; Failli, P.; Palomino, S.; et al. Acute visceral pain relief mediated by A3AR agonists in rats: Involvement of N-type voltage-gated calcium channels. Pain 2020, 161. [CrossRef]

47. Salvemini, D.; Jacobson, K.A. Highly selective A3 adenosine receptor agonists relieve chronic neuropathic pain. Expert Opin. Ther. Patents 2017, 27, 967. [CrossRef]

48. Ferreira-Silva, J.; Aires, I.D.; Boia, R.; Ambrósio, A.F.; Santiago, A.R. Activation of Adenosine A 3 Receptor Inhibits Microglia Reactivity Elicited by Elevated Pressure. Int. J. Mol. Sci. 2020, 21, 7218. [CrossRef]

49. Li, P.; Li, X.; Deng, P.; Wang, D.; Bai, X.; Li, Y.; Luo, C.; Belguise, K.; Wang, X.; Wei, X.; et al. Activation of adenosine A3 receptor reduces early brain injury by alleviating neuroinflammation after subarachnoid hemorrhage in elderly rats. Aging 2020, 13, 694-713. [CrossRef]

50. Farr, S.A.; Cuzzocrea, S.; Esposito, E.; Campolo, M.; Niehoff, M.L.; Doyle, T.M.; Salvemini, D. Adenosine A3 receptor as a novel therapeutic target to reduce secondary events and improve neurocognitive functions following traumatic brain injury. $J$. Neuroinflamm. 2020, 17, 339. [CrossRef]

51. Merighi, S.; Poloni, T.E.; Pelloni, L.; Pasquini, S.; Varani, K.; Vincenzi, F.; Borea, P.A.; Gessi, S. An Open Question: Is the A2A Adenosine Receptor a Novel Target for Alzheimer's Disease Treatment? Front. Pharmacol. 2021, 12. [CrossRef]

52. Rebola, N.; Canas, P.; Oliveira, C.; Cunha, R. Different synaptic and subsynaptic localization of adenosine A2A receptors in the hippocampus and striatum of the rat. Neuroscience 2005, 132, 893-903. [CrossRef]

53. Orr, A.G.; Orr, A.L.; Li, X.-J.; Gross, R.E.; Traynelis, S.F. Adenosine A2A receptor mediates microglial process retraction. Nat. Neurosci. 2009, 12, 872-878. [CrossRef]

54. Rebola, N.; Simões, A.P.; Canas, P.M.; Tomé, A.R.; Andrade, G.; Barry, C.E.; Agostinho, P.M.; Lynch, M.A.; Cunha, R.A. Adenosine A2A receptors control neuroinflammation and consequent hippocampal neuronal dysfunction. J. Neurochem. 2011, 117, 100-111. [CrossRef]

55. Cunha, R.A.; Johansson, B.; Van Der Ploeg, I.; Sebastião, A.M.; Ribeiro, J.A.; Fredholm, B.B. Evidence for functionally important adenosine A2a receptors in the rat hippocampus. Brain Res. 1994, 649, 208-216. [CrossRef]

56. Temido-Ferreira, M.; Ferreira, D.G.; Batalha, V.L.; Marques-Morgado, I.; Coelho, J.E.; Pereira, P.; Gomes, R.; Pinto, A.; Carvalho, S.; Canas, P.M.; et al. Age-related shift in LTD is dependent on neuronal adenosine A2A receptors interplay with mGluR5 and NMDA receptors. Mol. Psychiatry 2020, 25, 1876-1900. [CrossRef]

57. Horgusluoglu-Moloch, E.; Nho, K.; Risacher, S.L.; Kim, S.; Foroud, T.; Shaw, L.M.; Trojanowski, J.Q.; Aisen, P.S.; Petersen, R.C.; Jack, C.R.; et al. Targeted neurogenesis pathway-based gene analysis identifies ADORA2A associated with hippocampal volume in mild cognitive impairment and Alzheimer's disease. Neurobiol. Aging 2017, 60, 92-103. [CrossRef]

58. Canas, P.M.; Porciúncula, L.O.; Cunha, G.M.A.; Silva, C.G.; Machado, N.J.; Oliveira, J.M.A.; Oliveira, C.R.; Cunha, R.A. Adenosine A2A Receptor Blockade Prevents Synaptotoxicity and Memory Dysfunction Caused by $\beta$-Amyloid Peptides via p38 MitogenActivated Protein Kinase Pathway. J. Neurosci. 2009, 29, 14741-14751. [CrossRef] [PubMed]

59. Selkoe, D.J. Alzheimer's Disease Is a Synaptic Failure. Science 2002, 298, 789-791. [CrossRef]

60. Scheff, S.W.; Price, D.A.; Schmitt, F.A.; DeKosky, S.T.; Mufson, E.J. Synaptic alterations in CA1 in mild Alzheimer disease and mild cognitive impairment. Neurology 2007, 68, 1501-1508. [CrossRef]

61. Scheff, S.W.; Price, D.A.; Ansari, M.A.; Roberts, K.N.; Schmitt, F.A.; Ikonomovic, M.D.; Mufson, E.J. Synaptic Change in the Posterior Cingulate Gyrus in the Progression of Alzheimer's Disease. J. Alzheimer's Dis. 2014, 43, 1073-1090. [CrossRef]

62. Lopes, L.V.; Cunha, R.A.; Ribeiro, J.A. Increase in the Number, G Protein Coupling, and Efficiency of Facilitatory Adenosine A2A Receptors in the Limbic Cortex, but not Striatum, of Aged Rats. J. Neurochem. 2002, 73, 1733-1738. [CrossRef] [PubMed]

63. Li, P.; Rial, D.; Canas, P.M.; Yoo, J.-H.; Li, W.; Zhou, X.; Wang, Y.; Van Westen, G.J.P.; Payen, M.-P.; Augusto, E.; et al. Optogenetic activation of intracellular adenosine A2A receptor signaling in the hippocampus is sufficient to trigger CREB phosphorylation and impair memory. Mol. Psychiatry 2015, 20, 1339-1349. [CrossRef]

64. Pagnussat, N.; Almeida, A.S.; Marques, D.M.; Nunes, F.S.; Chenet, G.C.; Botton, P.H.S.; Mioranzza, S.; Loss, C.M.; Cunha, R.A.; Porciuncula, L.O. Adenosine A2Areceptors are necessary and sufficient to trigger memory impairment in adult mice. Br. J. Pharmacol. 2015, 172, 3831-3845. [CrossRef] [PubMed]

65. Albasanz, J.L.; Perez, S.M.; Barrachina, M.; Ferrer, I.; Martín, M. RESEARCH ARTICLE: Up-regulation of Adenosine Receptors in the Frontal Cortex in Alzheimer's Disease. Brain Pathol. 2008, 18, 211-219. [CrossRef] [PubMed]

66. Orr, A.G.; Hsiao, E.C.; Wang, M.M.; Ho, K.; Kim, D.H.; Wang, X.; Guo, W.; Kang, J.; Yu, G.-Q.; Adame, A.; et al. Astrocytic adenosine receptor A2A and Gs-coupled signaling regulate memory. Nat. Neurosci. 2015, 18, 423-434. [CrossRef] [PubMed] 
67. Arendash, G.; Schleif, W.; Rezai-Zadeh, K.; Jackson, E.; Zacharia, L.; Cracchiolo, J.; Shippy, D.; Tan, J. Caffeine protects Alzheimer's mice against cognitive impairment and reduces brain $\beta$-amyloid production. Neuroscience 2006, 142, 941-952. [CrossRef]

68. Espinosa, J.; Rocha, A.; Nunes, F.; Costa, M.S.; Schein, V.; Kazlauckas, V.; Kalinine, E.; Souza, D.O.; Cunha, R.A.; Porciúncula, L.O. Caffeine Consumption Prevents Memory Impairment, Neuronal Damage, and Adenosine A2A Receptors Upregulation in the Hippocampus of a Rat Model of Sporadic Dementia. J. Alzheimer's Dis. 2013, 34, 509-518. [CrossRef]

69. Merighi, S.; Battistello, E.; Casetta, I.; Gragnaniello, D.; Poloni, T.E.; Medici, V.; Cirrincione, A.; Varani, K.; Vincenzi, F.; Borea, P.A.; et al. Upregulation of Cortical $\mathrm{A}_{2} \mathrm{~A}$ Adenosine Receptors is Reflected in Platelets of Patients with Alzheimer's Disease. J. Alzheimer's Dis. 2021, 80, 1105-1117. [CrossRef]

70. da Silva, S.V.; Haberl, M.G.; Zhang, P.; Bethge, P.; Lemos, C.; Gonçalves, N.; Gorlewicz, A.; Malezieux, M.; Gonçalves, F.Q.; Grosjean, N.; et al. Early synaptic deficits in the APP/PS1 mouse model of Alzheimer's disease involve neuronal adenosine A2A receptors. Nat. Commun. 2016, 7, 11915. [CrossRef]

71. Cunha, R.A. How does adenosine control neuronal dysfunction and neurodegeneration? J. Neurochem. 2016, 139, 1019-1055. [CrossRef]

72. Shen, L.L.; Li, W.W.; Xu, Y.L.; Gao, S.H.; Xu, M.Y.; Bu, X.L.; Liu, Y.H.; Wang, J.; Zhu, J.; Zeng, F.; et al. Neurotrophin receptor p75 mediates amyloid $\beta$-induced tau pathology. Neurobiol. Dis. 2019, 132, 104567. [CrossRef]

73. Dall'Igna, O.P.; Fett, P.; Gomes, M.W.; Souza, D.O.; Cunha, R.A.; Lara, D.R. Caffeine and adenosine A2a receptor antagonists prevent $\beta$-amyloid (25-35)-induced cognitive deficits in mice. Exp. Neurol. 2007, 203, 241-245. [CrossRef] [PubMed]

74. Orr, A.G.; Lo, I.; Schumacher, H.; Ho, K.; Gill, M.; Guo, W.; Kim, D.H.; Knox, A.; Saito, T.; Saido, T.C.; et al. Istradefylline reduces memory deficits in aging mice with amyloid pathology. Neurobiol. Dis. 2018, 110, 29-36. [CrossRef]

75. Laurent, C.; Burnouf, S.; Ferry, B.; Batalha, V.L.; Coelho, J.E.; Baqi, Y.; Malik, E.; Mariciniak, E.; Parrot, S.; Van Der Jeugd, A.; et al. $\mathrm{A}_{2 \mathrm{~A}}$ adenosine receptor deletion is protective in a mouse model of Tauopathy. Mol. Psychiatry 2016, 21, 97-107. [CrossRef]

76. Carvalho, K.; Faivre, E.; Pietrowski, M.J.; Marques, X.; Gomez-Murcia, V.; Deleau, A.; Huin, V.; Hansen, J.N.; Kozlov, S.; Danis, C.; et al. Exacerbation of $\mathrm{C} 1 \mathrm{q}$ dysregulation, synaptic loss and memory deficits in tau pathology linked to neuronal adenosine A2A receptor. Brain 2019, 142, 3636-3654. [CrossRef] [PubMed]

77. Santiago, A.R.; Baptista, F.I.; Santos, P.F.; Cristovão, G.; Ambrosio, A.F.; Cunha, R.A.; Gomes, C.A. Role of Microglia Adenosine A2AReceptors in Retinal and Brain Neurodegenerative Diseases. Mediat. Inflamm. 2014, 2014, 465694. [CrossRef]

78. Illes, P.; Rubini, P.; Ulrich, H.; Zhao, Y.; Tang, Y. Regulation of Microglial Functions by Purinergic Mechanisms in the Healthy and Diseased CNS. Cells 2020, 9, 1108. [CrossRef]

79. Franco, R.; Reyes-Resina, I.; Aguinaga, D.; Lillo, A.; Jiménez, J.; Raïch, I.; Borroto-Escuela, D.O.; Ferreiro-Vera, C.; Canela, E.I.; De Medina, V.S.; et al. Potentiation of cannabinoid signaling in microglia by adenosine A 2A receptor antagonists. Glia 2019, 67, 2410-2423. [CrossRef]

80. Colella, M.; Zinni, M.; Pansiot, J.; Cassanello, M.; Mairesse, J.; Ramenghi, L.; Baud, O. Modulation of Microglial Activation by Adenosine A2a Receptor in Animal Models of Perinatal Brain Injury. Front. Neurol. 2018, 9, 605. [CrossRef]

81. Franco, R.; Rivas-Santisteban, R.; Casanovas, M.; Lillo, A.; Saura, C.A.; Navarro, G. Adenosine A2A Receptor Antagonists Affects NMDA Glutamate Receptor Function. Potential to Address Neurodegeneration in Alzheimer's Disease. Cells 2020, 9 , 1075. [CrossRef]

82. Rebola, N.; Lujan, R.; Cunha, R.A.; Mulle, C. Adenosine $A_{2 A}$ Receptors Are Essential for Long-Term Potentiation of NMDA-EPSCs at Hippocampal Mossy Fiber Synapses. Neuron 2008, 57, 121-134. [CrossRef] [PubMed]

83. Mouro, F.M.; Rombo, D.M.; Dias, R.B.; Ribeiro, J.A.; Sebastião, A.M. Adenosine A2A receptors facilitate synaptic NMDA currents in CA1 pyramidal neurons. Br. J. Pharmacol. 2018, 175, 4386-4397. [CrossRef] [PubMed]

84. Hansen, D.V.; Hansen, J.; Sheng, M. Microglia in Alzheimer's disease. J. Cell Biol. 2018, 217, 459-472. [CrossRef] [PubMed]

85. Chambers, E.S.; Akbar, A.N. Can blocking inflammation enhance immunity during aging? J. Allergy Clin. Immunol. 2020, 145, 1323-1331. [CrossRef]

86. Yates, S.L.; Burgess, L.H.; Kocsis-Angle, J.; Antal, J.M.; Dority, M.D.; Embury, P.B.; Piotrkowski, A.M.; Brunden, K.R. Amyloid $\beta$ and Amylin Fibrils Induce Increases in Proinflammatory Cytokine and Chemokine Production by THP-1 Cells and Murine Microglia. J. Neurochem. 2000, 74, 1017-1025. [CrossRef]

87. Shieh, C.-H.; Heinrich, A.; Serchov, T.; Van Calker, D.; Biber, K. P2X7-dependent, but differentially regulated release of IL-6, CCL2, and TNF- $\alpha$ in cultured mouse microglia. Glia 2014, 62, 592-607. [CrossRef]

88. Calovi, S.; Mut-Arbona, P.; Sperlágh, B. Microglia and the Purinergic Signaling System. Neuroscience 2019, 405, 137-147. [CrossRef]

89. Koizumi, S.; Shigemoto-Mogami, Y.; Nasu-Tada, K.; Shinozaki, Y.; Ohsawa, K.; Tsuda, M.; Joshi, B.V.; Jacobson, K.A.; Kohsaka, S.; Inoue, K. UDP acting at P2Y6 receptors is a mediator of microglial phagocytosis. Nature 2007, 446, 1091-1095. [CrossRef]

90. Koizumi, S.; Ohsawa, K.; Inoue, K.; Kohsaka, S. Purinergic receptors in microglia: Functional modal shifts of microglia mediated by P2 and P1 receptors. Glia 2012, 61, 47-54. [CrossRef]

91. Kim, S.Y.; Moon, J.H.; Lee, H.G.; Kim, S.U.; Beom Lee, Y.B. ATP released from beta-amyloid-stimulated microglia induces reactive oxygen species production in an autocrine fashion. Exp. Mol. Med. 2007, 39, 820-827. [CrossRef]

92. Rampe, D.; Wang, L.; Ringheim, G.E. P2X7 receptor modulation of $\beta$-amyloid- and LPS-induced cytokine secretion from human macrophages and microglia. J. Neuroimmunol. 2004, 147, 56-61. [CrossRef]

93. Sanz, J.M.; Chiozzi, P.; Ferrari, D.; Colaianna, M.; Idzko, M.; Falzoni, S.; Fellin, R.; Trabace, L.; Di Virgilio, F. Activation of microglia by amyloid $\beta$ requires P2X7 receptor expression. J. Immunol. 2009, 182, 4378-4385. [CrossRef] 
94. Idzko, M.; Ferrari, D.; Eltzschig, H.K. Nucleotide signalling during inflammation. Nature 2014, 509, 310-317. [CrossRef] [PubMed]

95. Labasi, J.M.; Petrushova, N.; Donovan, C.; McCurdy, S.; Lira, P.; Payette, M.M.; Brissette, W.; Wicks, J.R.; Audoly, L.; Gabel, C.A. Absence of the P2X7Receptor Alters Leukocyte Function and Attenuates an Inflammatory Response. J. Immunol. 2002, 168, 6436-6445. [CrossRef] [PubMed]

96. Ryu, J.K.; McLarnon, J.G. Block of purinergic P2X7 receptor is neuroprotective in an animal model of Alzheimer's disease. NeuroReport 2008, 19, 1715-1719. [CrossRef]

97. Hide, I.; Tanaka, M.; Inoue, A.; Nakajima, K.; Kohsaka, S.; Inoue, K.; Nakata, Y. Extracellular ATP Triggers Tumor Necrosis Factor- $\alpha$ Release from Rat Microglia. J. Neurochem. 2002, 75, 965-972. [CrossRef]

98. Simi, A.; Tsakiri, N.; Wang, P.; Rothwell, N.J. Interleukin-1 and inflammatory neurodegeneration. Biochem. Soc. Trans. 2007, 35, 1122-1126. [CrossRef] [PubMed]

99. Patel, N.S.; Paris, D.; Mathura, V.; Quadros, A.N.; Crawford, F.C.; Mullan, M.J. Inflammatory cytokine levels correlate with amyloid load in transgenic mouse models of Alzheimer's disease. J. Neuroinflamm. 2005, 2, 9. [CrossRef]

100. Parajuli, B.; Sonobe, Y.; Horiuchi, H.; Takeuchi, H.; Mizuno, T.; Suzumura, A. Oligomeric amyloid $\beta$ induces IL-1 $\beta$ processing via production of ROS: Implication in Alzheimer's disease. Cell Death Dis. 2013, 4, e975. [CrossRef]

101. Martin, E.; Amar, M.; Dalle, C.; Youssef, I.; Boucher, C.; Le Duigou, C.; Brückner, M.; Prigent, A.; Sazdovitch, V.; Halle, A.; et al. New role of P2X7 receptor in an Alzheimer's disease mouse model. Mol. Psychiatry 2019, 24, 108-125. [CrossRef]

102. Able, S.; Fish, R.; Bye, H.; Booth, L.; Logan, Y.; Nathaniel, C.; Hayter, P.; Katugampola, S. Receptor localization, native tissue binding and ex vivo occupancy for centrally penetrant P2X7 antagonists in the rat. Br. J. Pharmacol. 2010, 162, 405-414. [CrossRef]

103. Eskelinen, M.H.; Ngandu, T.; Tuomilehto, J.; Soininen, H.; Kivipelto, M. Midlife Coffee and Tea Drinking and the Risk of Late-Life Dementia: A Population-Based CAIDE Study. J. Alzheimer's Dis. 2009, 16, 85-91. [CrossRef]

104. Eskelinen, M.H.; Kivipelto, M. Caffeine as a Protective Factor in Dementia and Alzheimer's Disease. J. Alzheimer's Dis. 2010, 20, S167-S174. [CrossRef]

105. Gelber, R.P.; Petrovitch, H.; Masaki, K.H.; Ross, G.W.; White, L.R. Coffee Intake in Midlife and Risk of Dementia and its Neuropathologic Correlates. J. Alzheimer's Dis. 2011, 23, 607-615. [CrossRef]

106. Liu, Q.-P.; Wu, Y.-F.; Cheng, H.-Y.; Xia, T.; Ding, H.; Wang, H.; Wang, Z.-M.; Xu, Y. Habitual coffee consumption and risk of cognitive decline/dementia: A systematic review and meta-analysis of prospective cohort studies. Nutrition 2016, 32, 628-636. [CrossRef] [PubMed]

107. Reyes, C.M.; Cornelis, M.C. Caffeine in the Diet: Country-Level Consumption and Guidelines. Nutrition $2018,10,1772$. [CrossRef] [PubMed]

108. Santos, C.; Costa, J.; Santos, J.; Vaz-Carneiro, A.; Lunet, N. Caffeine Intake and Dementia: Systematic Review and Meta-Analysis. J. Alzheimer's Dis. 2010, 20, S187-S204. [CrossRef] [PubMed]

109. Sugiyama, K.; Tomata, Y.; Kaiho, Y.; Honkura, K.; Sugawara, Y.; Tsuji, I. Association between Coffee Consumption and Incident Risk of Disabling Dementia in Elderly Japanese: The Ohsaki Cohort 2006 Study. J. Alzheimer's Dis. 2015, 50, 491-500. [CrossRef] [PubMed]

110. Dong, X.; Li, S.; Sun, J.; Li, Y.; Zhang, D. Association of Coffee, Decaffeinated Coffee and Caffeine Intake from Coffee with Cognitive Performance in Older Adults: National Health and Nutrition Examination Survey (NHANES) 2011-2014. Nutrients 2020, 12, 840. [CrossRef]

111. Iranpour, S.; Saadati, H.M.; Koohi, F.; Sabour, S. Association between caffeine intake and cognitive function in adults; effect modification by sex: Data from National Health and Nutrition Examination Survey (NHANES) 2013-2014. Clin. Nutr. 2020, 39, 2158-2168. [CrossRef]

112. Yu, L.; Coelho, J.E.; Zhang, X.; Fu, Y.; Tillman, A.; Karaoz, U.; Fredholm, B.B.; Weng, Z.; Chen, J.-F. Uncovering multiple molecular targets for caffeine using a drug target validation strategy combining $\mathrm{A}_{2 \mathrm{~A}}$ receptor knockout mice with microarray profiling. Physiol. Genom. 2009, 37, 199-210. [CrossRef] [PubMed]

113. Lopes, J.P.; Pliássova, A.; Cunha, R.A. The physiological effects of caffeine on synaptic transmission and plasticity in the mouse hippocampus selectively depend on adenosine $\mathrm{A}_{1}$ and $\mathrm{A}_{2 \mathrm{~A}}$ receptors. Biochem. Pharmacol. 2019, 166, 313-321. [CrossRef] [PubMed]

114. Jacobson, K.A.; Gao, Z.; Matricon, P.; Eddy, M.T.; Carlsson, J. Adenosine $\mathrm{A}_{2 \mathrm{~A}}$ receptor antagonists: From caffeine to selective non-xanthines. Br. J. Pharmacol. 2020. [CrossRef]

115. Maia, L.; De Mendonca, A. Does caffeine intake protect from Alzheimer's disease? Eur. J. Neurol. 2002, 9, 377-382. [CrossRef]

116. Lindsay, J.; Laurin, D.; Verreault, R.; Hébert, R.; Helliwell, B.; Hill, G.B.; McDowell, I. Risk Factors for Alzheimer's Disease: A Prospective Analysis from the Canadian Study of Health and Aging. Am. J. Epidemiol. 2002, 156, 445-453. [CrossRef] [PubMed]

117. Van Gelder, B.M.; Buijsse, B.; Tijhuis, M.; Kalmijn, S.; Giampaoli, S.; Nissinen, A.; Kromhout, D. Coffee consumption is inversely associated with cognitive decline in elderly European men: The FINE Study. Eur. J. Clin. Nutr. 2006, 61, 226-232. [CrossRef]

118. Ritchie, K.; Carrière, I.; De Mendonca, A.; Portet, F.; Dartigues, J.-F.; Rouaud, O.; Barberger-Gateau, P.; Ancelin, M.-L. The neuroprotective effects of caffeine: A prospective population study (the Three City Study). Neurology 2007, 69, 536-545. [CrossRef]

119. Cao, C.; Loewenstein, D.A.; Lin, X.; Zhang, C.; Wang, L.; Duara, R.; Wu, Y.; Giannini, A.; Bai, G.; Cai, J.; et al. High Blood Caffeine Levels in MCI Linked to Lack of Progression to Dementia. J. Alzheimer's Dis. 2012, 30, 559-572. [CrossRef]

120. Potter, H.; Woodcock, J.H.; Boyd, T.D.; Coughlan, C.M.; O’Shaughnessy, J.R.; Borges, M.T.; Thaker, A.A.; Raj, B.A.; Adamszuk, K.; Scott, D.; et al. Safety and efficacy of sargramostim (GM-CSF) in the treatment of Alzheimer's disease. Alzheimer's Dement. 2021, 7, e12158. [CrossRef] 
121. Laske, C.; Stellos, K.; Stransky, E.; Leyhe, T.; Gawaz, M. Decreased Plasma Levels of Granulocyte-Colony Stimulating Factor (G-CSF) in Patients with Early Alzheimer's Disease. J. Alzheimer's Dis. 2009, 17, 115-123. [CrossRef]

122. Zotova, E.; Bharambe, V.; Cheaveau, M.; Morgan, W.; Holmes, C.; Harris, S.; Neal, J.W.; Love, S.; Nicoll, J.A.R.; Boche, D. Inflammatory components in human Alzheimer's disease and after active amyloid- $\beta 42$ immunization. Brain 2013, 136, 2677-2696. [CrossRef]

123. Mejias, N.H.; Martinez, C.C.; Stephens, M.E.; de Rivero Vaccari, J.P. Contribution of the inflammasome to inflammaging. J. Inflamm. (Lond). 2018, 15, 23. [CrossRef] [PubMed]

124. Borota, D.; Murray, E.; Keceli, G.; Chang, A.; Watabe, J.M.; Ly, M.; Toscano, J.P.; Yassa, M.A. Post-study caffeine administration enhances memory consolidation in humans. Nat. Neurosci. 2014, 17, 201-203. [CrossRef] [PubMed]

125. Favila, S.E.; Kuhl, B.A. Stimulating memory consolidation. Nat. Neurosci. 2014, 17, 151-152. [CrossRef]

126. Arendash, G.W.; Mori, T.; Cao, C.; Mamcarz, M.; Runfeldt, M.; Dickson, A.; Rezai-Zadeh, K.; Tane, J.; Citron, B.A.; Lin, X.; et al. Caffeine reverses cognitive impairment and decreases brain amyloid- $\beta$ levels in aged Alzheimer's disease mice. J. Alzheimer's Dis. 2009, 17, 661-680. [CrossRef] [PubMed]

127. Canas, P.M.; Porciúncula, L.O.; Simões, A.P.; Augusto, E.; Silva, H.B.; Machado, N.J.; Gonçalves, N.; Alfaro, T.M.; Gonçalves, F.Q.; Araujo, I.; et al. Neuronal Adenosine A2A Receptors Are Critical Mediators of Neurodegeneration Triggered by Convulsions. eNeuro 2018, 5. [CrossRef]

128. Cao, C.; Cirrito, J.R.; Lin, X.; Wang, L.; Verges, D.K.; Dickson, A.; Mamcarz, M.; Zhang, C.; Mori, T.; Arendash, G.W.; et al. Caffeine Suppresses Amyloid- $\beta$ Levels in Plasma and Brain of Alzheimer's Disease Transgenic Mice. J. Alzheimer's Dis. 2009, 17, 681-697. [CrossRef] [PubMed]

129. Laurent, C.; Eddarkaoui, S.; Derisbourg, M.; Leboucher, A.; Demeyer, D.; Carrier, S.; Schneider, M.; Hamdane, M.; Müller, C.E.; Buée, L.; et al. Beneficial effects of caffeine in a transgenic model of Alzheimer's disease-like tau pathology. Neurobiol. Aging 2014, 35, 2079-2090. [CrossRef]

130. Kolahdouzan, M.; Hamadeh, M.J. The neuroprotective effects of caffeine in neurodegenerative diseases. CNS Neurosci. Ther. 2017, 23, 272-290. [CrossRef]

131. Costa, M.; Botton, P.; Mioranzza, S.; Souza, D.; Porciúncula, L. Caffeine prevents age-associated recognition memory decline and changes brain-derived neurotrophic factor and tirosine kinase receptor (TrkB) content in mice. Neuroscience 2008, 153, 1071-1078. [CrossRef]

132. Kaster, M.P.; Machado, N.J.; Silva, H.B.; Nunes, A.; Ardais, A.P.; Santana, M.; Baqi, Y.; Müller, C.E.; Rodrigues, A.L.S.; Porciúncula, L.O.; et al. Caffeine acts through neuronal adenosine $\mathrm{A}_{2} \mathrm{~A}$ receptors to prevent mood and memory dysfunction triggered by chronic stress. Proc. Natl. Acad. Sci. USA 2015, 112, 7833-7838. [CrossRef] [PubMed]

133. Janitschke, D.; Nelke, C.; Lauer, A.A.; Regner, L.; Winkler, J.; Thiel, A.; Grimm, H.S.; Hartmann, T.; Grimm, M.O.W. Effect of Caffeine and Other Methylxanthines on A $\beta$-Homeostasis in SH-SY5Y Cells. Biomolecules 2019, 9, 689. [CrossRef] [PubMed]

134. Sinyor, B.; Mineo, J.; Ochner, C. Alzheimer's Disease, Inflammation, and the Role of Antioxidants. J. Alzheimer's Dis. Rep. 2020, 4, 175-183. [CrossRef] [PubMed]

135. Travassos, M.; Santana, I.; Baldeiras, I.; Tsolaki, M.; Gkatzima, O.; Sermin, G.; Yener, G.G.; Simonsen, A.; Hasselbalch, S.G.; Kapaki, E.; et al. Does Caffeine Consumption Modify Cerebrospinal Fluid Amyloid- $\beta$ Levels in Patients with Alzheimer's Disease? J. Alzheimer's Dis. 2015, 47, 1069-1078. [CrossRef] [PubMed]

136. Moreira, A.; Diógenes, M.J.; De Mendonça, A.; Lunet, N.; Barros, H. Chocolate Consumption is Associated with a Lower Risk of Cognitive Decline. J. Alzheimer's Dis. 2016, 53, 85-93. [CrossRef] [PubMed]

137. Borea, P.A.; Gessi, S.; Merighi, S.; Vincenzi, F.; Varani, K. Pathological overproduction: The bad side of adenosine. Br. J. Pharmacol. 2017, 174, 1945-1960. [CrossRef]

138. Chen, J.-F.; Cunha, R.A. The belated US FDA approval of the adenosine A2A receptor antagonist istradefylline for treatment of Parkinson's disease. Purinergic Signal. 2020, 16, 167-174. [CrossRef]

139. Von Kügelgen, I.; Hoffmann, K. Pharmacology and structure of P2Y receptors. Neuropharmacology 2016, 104, 50-61. [CrossRef]

140. Boeynaems, J.-M.; Communi, D.; Gonzalez, N.S.; Robaye, B. Overview of the P2 Receptors. Semin. Thromb. Hemost. 2005, 31, 139-149. [CrossRef] [PubMed]

141. Illes, P.; Ribeiro, J. Neuronal P2 Receptors of the Central Nervous System. Curr. Top. Med. Chem. 2004, 4, 831-838. [CrossRef]

142. Neary, J.T.; Kang, Y.; Shi, Y.-F.; Tran, M.D.; Wanner, I.B. P2 Receptor Signalling, Proliferation of Astrocytes, and Expression of Molecules Involved in Cell-Cell Interactions. In Purinergic Signalling in Neuron-Glia Interactions; Novartis Foundation Symposia; John Wiley \& Sons: Hoboken, NJ, USA, 2006; Volume 276, pp. 131-147. [CrossRef]

143. Tsuda, M.; Shigemoto-Mogami, Y.; Koizumi, S.; Mizokoshi, A.; Kohsaka, S.; Salter, M.W.; Inoue, K. P2X4 receptors induced in spinal microglia gate tactile allodynia after nerve injury. Nat. Cell Biol. 2003, 424, 778-783. [CrossRef] [PubMed]

144. Andrejew, R.; Oliveira-Giacomelli, Á.; Ribeiro, D.E.; Glaser, T.; Arnaud-Sampaio, V.F.; Lameu, C.; Ulrich, H. The P2X7 Receptor: Central Hub of Brain Diseases. Front. Mol. Neurosci. 2020, 13, 124. [CrossRef] [PubMed]

145. Sperlágh, B.; Vizi, E.S.; Wirkner, K.; Illes, P. P2X7 receptors in the nervous system. Prog. Neurobiol. 2006, 78, 327-346. [CrossRef]

146. Sluyter, R. Significance of P2X7 Receptor Variants to Human Health and Disease. Recent Patents DNA Gene Seq. 2011, 5, 41-54. [CrossRef] [PubMed]

147. Sengoku, R. Aging and Alzheimer's disease pathology. Neuropathology 2020, 40, 22-29. [CrossRef] 
148. Woods, L.T.; Ajit, D.; Camden, J.M.; Erb, L.; Weisman, G.A. Purinergic receptors as potential therapeutic targets in Alzheimer's disease. Neuropharmacology 2016, 104, 169-179. [CrossRef] [PubMed]

149. Berridge, M.J. Calcium signalling and Alzheimer's disease. Neurochem. Res. 2011, 36, 1149-1156. [CrossRef]

150. Pham, C.; Hérault, K.; Oheim, M.; Maldera, S.; Vialou, V.; Cauli, B.; Li, D. Astrocytes respond to a neurotoxic A $\beta$ fragment with state-dependent Ca2+ alteration and multiphasic transmitter release. Acta Neuropathol. Commun. 2021, 9, 44. [CrossRef]

151. Jin, H.; Han, J.; Resing, D.; Liu, H.; Yue, X.; Miller, R.L.; Schoch, K.M.; Miller, T.M.; Perlmutter, J.S.; Egan, T.M.; et al. Synthesis and in vitro characterization of a P2X7 radioligand [123I]TZ6019 and its response to neuroinflammation in a mouse model of Alzheimer disease. Eur. J. Pharmacol. 2018, 820, 8-17. [CrossRef]

152. McLarnon, J.G.; Ryu, M.J.K.; Walker, D.G.; Choi, B.H.B. Upregulated Expression of Purinergic P2X7Receptor in Alzheimer Disease and Amyloid- $\beta$ Peptide-Treated Microglia and in Peptide-Injected Rat Hippocampus. J. Neuropathol. Exp. Neurol. 2006, 65, 1090-1097. [CrossRef]

153. Gallart-Palau, X.; Serra, A.; Lee, B.S.T.; Guo, X.; Sze, S.K. Brain ureido degenerative protein modifications are associated with neuroinflammation and proteinopathy in Alzheimer's disease with cerebrovascular disease. J. Neuroinflamm. 2017, $14,175$. [CrossRef] [PubMed]

154. Savio, L.E.B.; Mello, P.D.A.; Da Silva, C.G.; Coutinho-Silva, R. The P2X7 receptor in inflammatory diseases: Angel or demon? Front. Pharmacol. 2018, 9, 52. [CrossRef]

155. Sanz, J.M.; Falzoni, S.; Rizzo, R.; Cipollone, F.; Zuliani, G.; Di Virgilio, F. Possible protective role of the 489C>T P2X7R polymorphism in Alzheimer's disease. Exp. Gerontol. 2014, 60, 117-119. [CrossRef] [PubMed]

156. Perregaux, D.G.; McNiff, P.; Laliberte, R.; Conklyn, M.; Gabel, C.A. ATP Acts as an Agonist to Promote Stimulus-Induced Secretion of IL-1 $\beta$ and IL-18 in Human Blood. J. Immunol. 2000, 165, 4615-4623. [CrossRef] [PubMed]

157. Solle, M.; Labasi, J.; Perregaux, D.G.; Stam, E.; Petrushova, N.; Koller, B.H.; Griffiths, R.J.; Gabel, C.A. Altered Cytokine Production in Mice Lacking P2X7Receptors. J. Biol. Chem. 2001, 276, 125-132. [CrossRef] [PubMed]

158. Browne, S.E. When too much ATP is a bad thing: A pivotal role for P2X7 receptors in motor neuron degeneration. J. Neurochem. 2013, 126, 301-304. [CrossRef] [PubMed]

159. Kong, Q.; Wang, M.; Liao, Z.; Camden, J.M.; Yu, S.; Simonyi, A.; Sun, G.Y.; Gonzalez, F.A.; Erb, L.; Seye, C.I.; et al. P2X7 nucleotide receptors mediate caspase-8/9/3-dependent apoptosis in rat primary cortical neurons. Purinergic Signal. 2005, 1, 337-347. [CrossRef] [PubMed]

160. Delarasse, C.; Auger, R.; Gonnord, P.; Fontaine, B.; Kanellopoulos, J.M. The Purinergic Receptor P2X7 Triggers $\alpha$-Secretasedependent Processing of the Amyloid Precursor Protein. J. Biol. Chem. 2011, 286, 2596-2606. [CrossRef]

161. León-Otegui, M.; Gómez-Villafuertes, R.; Díaz-Hernández, J.I.; Díaz-Hernández, M.; Miras-Portugal, M.T.; Gualix, J. Opposite effects of P2X7 and P2Y2nucleotide receptors on $\alpha$-secretase-dependent APP processing in Neuro-2a cells. FEBS Lett. 2011, 585, 2255-2262. [CrossRef]

162. Diaz-Hernandez, J.I.; Gomez-Villafuertes, R.; León-Otegui, M.; Hontecillas-Prieto, L.; Del Puerto, A.; Trejo, J.L.; Lucas, J.J.; Garrido, J.J.; Gualix, J.; Miras-Portugal, M.T.; et al. In vivo P2X7 inhibition reduces amyloid plaques in Alzheimer's disease through GSK3 $\beta$ and secretases. Neurobiol. Aging 2012, 33, 1816-1828. [CrossRef]

163. Miras-Portugal, M.T.; Diaz-Hernandez, J.I.; Gomez-Villafuertes, R.; Diaz-Hernandez, M.; Artalejo, A.R.; Gualix, J. Role of P2X7 and P2Y2 receptors on $\alpha$-secretase-dependent APP processing: Control of amyloid plaques formation "in vivo" by P2X7 receptor. Comput. Struct. Biotechnol. J. 2015, 13, 176-181. [CrossRef] [PubMed]

164. Sáez-Orellana, F.; Fuentes-Fuentes, M.C.; Godoy, P.A.; Silva-Grecchi, T.; Panes, J.D.; Guzmán, L.; Yévenes, G.E.; Gavilán, J.; Egan, T.M.; Aguayo, L.G.; et al. P2X receptor overexpression induced by soluble oligomers of amyloid beta peptide potentiates synaptic failure and neuronal dyshomeostasis in cellular models of Alzheimer's disease. Neuropharmacology 2018, 128, 366-378. [CrossRef]

165. Varma, R.; Chai, Y.; Troncoso, J.; Gu, J.; Xing, H.; Stojilkovic, S.S.; Mattson, M.P.; Haughey, N.J. Amyloid- $\beta$ Induces a Caspasemediated Cleavage of P2X4 to Promote Purinotoxicity. Neuromol. Med. 2009, 11, 63-75. [CrossRef] [PubMed]

166. Erb, L.; Woods, L.T.; Khalafalla, M.G.; Weisman, G.A. Purinergic signaling in Alzheimer's disease. Brain Res. Bull. 2019, 151, 25-37. [CrossRef]

167. Kong, Q.; Peterson, T.S.; Baker, O.; Stanley, E.; Camden, J.; Seye, C.I.; Erb, L.; Simonyi, A.; Wood, W.G.; Sun, G.Y.; et al. Interleukin1beta enhances nucleotide-induced and alpha-secretase-dependent amyloid precursor protein processing in rat primary cortical neurons via up-regulation of the P2Y(2) receptor. J. Neurochem. 2009, 109, 1300-1310. [CrossRef]

168. Reichenbach, N.; Delekate, A.; Breithausen, B.; Keppler, K.; Poll, S.; Schulte, T.; Peter, J.; Plescher, M.; Hansen, J.N.; Blank, N.; et al. P2Y1 receptor blockade normalizes network dysfunction and cognition in an Alzheimer's disease model. J. Exp. Med. 2018, 215, 1649-1663. [CrossRef] [PubMed]

169. Delekate, A.; Füchtemeier, M.; Schumacher, T.; Ulbrich, C.; Foddis, M.; Petzold, G.C. Metabotropic P2Y1 receptor signalling mediates astrocytic hyperactivity in vivo in an Alzheimer's disease mouse model. Nat. Commun. 2014, 5, 5422. [CrossRef]

170. Kim, H.J.; Ajit, D.; Peterson, T.S.; Wang, Y.; Camden, J.M.; Wood, W.G.; Sun, G.Y.; Erb, L.; Petris, M.; Weisman, G.A. Nucleotides released from $A \beta_{1-42}$-treated microglial cells increase cell migration and $A \beta_{1-42}$ uptake through $\mathrm{P} 2 \mathrm{Y}_{2}$ receptor activation. J. Neurochem. 2012, 121, 228-238. [CrossRef] [PubMed]

171. Li, H.-Q.; Chen, C.; Dou, Y.; Wu, H.-J.; Liu, Y.-J.; Lou, H.-F.; Zhang, J.-M.; Li, X.-M.; Wang, H.; Duan, S. P2Y4 ReceptorMediated Pinocytosis Contributes to Amyloid Beta-Induced Self-Uptake by Microglia. Mol. Cell. Biol. 2013, 33, 4282-4293. [CrossRef] [PubMed] 
172. Thawkar, B.S.; Kaur, G. Inhibitors of NF-kB and P2X7/NLRP3/Caspase 1 pathway in microglia: Novel therapeutic opportunities in neuroinflammation induced early-stage Alzheimer's disease. J. Neuroimmunol. 2019, 326, 62-74. [CrossRef] [PubMed]

173. Temido-Ferreira, M.; Coelho, J.E.; Pousinha, P.A.; Lopes, L.V. Novel Players in the Aging Synapse: Impact on Cognition. J. Caffeine Adenosine Res. 2019, 9, 104-127. [CrossRef] [PubMed]

174. Haynes, S.E.; Hollopeter, G.; Yang, G.; Kurpius, D.; Dailey, M.E.; Gan, W.-B.; Julius, D. The P2Y12 receptor regulates microglial activation by extracellular nucleotides. Nat. Neurosci. 2006, 9, 1512-1519. [CrossRef]

175. Arulkumaran, N.; Unwin, R.J.; Tam, F.W.K. A potential therapeutic role for P2X7 receptor (P2X7R) antagonists in the treatment of inflammatory diseases. Expert Opin. Investig. Drugs 2011, 20, 897-915. [CrossRef] [PubMed]

176. Chrovian, C.C.; Rech, J.C.; Bhattacharya, A.; Letavic, M.A. P2X7 Antagonists as Potential Therapeutic Agents for the Treatment of CNS Disorders. Prog. Med. Chem. 2014, 53, 65-100. [CrossRef] [PubMed]

177. Rech, J.C.; Bhattacharya, A.; Letavic, M.A.; Savall, B.M. The evolution of P2X7 antagonists with a focus on CNS indications. Bioorg. Med. Chem. Lett. 2016, 26, 3838-3845. [CrossRef] [PubMed]

178. Labrousse, V.; Costes, L.; Aubert, A.; Darnaudéry, M.; Ferreira, G.; Amédée, T.; Layé, S. Impaired interleukin-1 $\beta$ and c-Fos expression in the hippocampus is associated with a spatial memory deficit in P2X7 receptor-deficient mice. PLoS ONE 2009, 4, e6006. [CrossRef] [PubMed]

179. Gelin, C.F.; Bhattacharya, A.; Letavic, M.A. P2X7 receptor antagonists for the treatment of systemic inflammatory disorders. Prog. Med. Chem. 2020, 59, 63-99. [CrossRef]

180. Takenouchi, T.; Sekiyama, K.; Sekigawa, A.; Fujita, M.; Waragai, M.; Sugama, S.; Iwamaru, Y.; Kitani, H.; Hashimoto, M. P2X7 Receptor Signaling Pathway as a Therapeutic Target for Neurodegenerative Diseases. Arch. Immunol. Ther. Exp. 2010, 58, 91-96. [CrossRef]

181. Domingos, L.; Hott, S.; Terzian, A.; Resstel, L. P2X7 purinergic receptors participate in the expression and extinction processes of contextual fear conditioning memory in mice. Neuropharmacology 2018, 128, 474-481. [CrossRef]

182. Borzelleca, J.; Depukat, K.; Hallagan, J. Lifetime toxicity/carcinogenicity studies of FD \& C blue No. 1 (Brilliant blue FCF) in rats and mice. Food Chem. Toxicol. 1990, 28, 221-234. [CrossRef]

183. Gao, M.; Wang, M.; Green, M.A.; Hutchins, G.D.; Zheng, Q.-H. Synthesis of $\left[{ }^{11}\right.$ C]GSK1482160 as a new PET agent for targeting P2X7 receptor. Bioorg. Med. Chem. Lett. 2015, 25, 1965-1970. [CrossRef] [PubMed]

184. Territo, P.R.; Meyer, J.A.; Peters, J.S.; Riley, A.A.; McCarthy, B.P.; Gao, M.; Wang, M.; Green, M.A.; Zheng, Q.-H.; Hutchins, G.D. Characterization of 11 C-GSK1482160 for Targeting the P2X7 Receptor as a Biomarker for Neuroinflammation. J. Nucl. Med. 2017, 58, 458-465. [CrossRef] [PubMed]

185. Baudelet, D.; Lipka, E.; Millet, R.; Ghinet, A. Involvement of the P2X7 purinergic receptor in inflammation: An update of antagonists series since 2009 and their promising therapeutic potential. Curr. Med. Chem. 2015, 22, 713-729. [CrossRef]

186. Murphy, N.; Cowley, T.R.; Richardson, J.C.; Virley, D.; Upton, N.; Walter, D.; Lynch, M.A. The Neuroprotective Effect of a Specific P2X7 Receptor Antagonist Derives from its Ability to Inhibit Assembly of the NLRP3 Inflammasome in Glial Cells. Brain Pathol. 2011, 22, 295-306. [CrossRef]

187. Bhattacharya, A.; Ceusters, M. Targeting neuroinflammation with brain penetrant P2X7 antagonists as novel therapeutics for neuropsychiatric disorders. Neuropsychopharmacology 2020, 45, 234-235. [CrossRef] [PubMed]

188. Parvathenani, L.K.; Tertyshnikova, S.; Greco, C.R.; Roberts, S.B.; Robertson, B.; Posmantur, R. P2X7 Mediates Superoxide Production in Primary Microglia and Is Up-regulated in a Transgenic Mouse Model of Alzheimer's Disease. J. Biol. Chem. 2003, 278, 13309-13317. [CrossRef] [PubMed]

189. Letavic, M.A.; Savall, B.M.; Allison, B.D.; Aluisio, L.; Andres, J.I.; De Angelis, M.; Ao, H.; Beauchamp, D.A.; Bonaventure, P.; Bryant, S.; et al. 4-Methyl-6,7-dihydro-4H-triazolo[4,5-c]pyridine-Based P2X7 Receptor Antagonists: Optimization of Pharmacokinetic Properties Leading to the Identification of a Clinical Candidate. J. Med. Chem. 2017, 60, 4559-4572. [CrossRef]

190. Danino, O.; Grossman, S.; Fischer, B. ATP- $\gamma-\mathrm{S}-(\alpha, \beta-\mathrm{CH} 2)$ protects against oxidative stress and amyloid beta toxicity in neuronal culture. Biochem. Biophys. Res. Commun. 2015, 460, 446-450. [CrossRef] [PubMed]

191. Espada, S.; Ortega, F.; Molina-Jijón, E.; Rojo, A.I.; Pérez-Sen, R.; Pedraza-Chaverri, J.; Miras-Portugal, M.T.; Cuadrado, A. The purinergic P2Y13 receptor activates the Nrf2/HO-1 axis and protects against oxidative stress-induced neuronal death. Free Radic. Biol. Med. 2010, 49, 416-426. [CrossRef] 